\title{
The archaeometallurgical reconstruction of early second- millennium AD metal production activities at Shankare Hill, northern Lowveld, South Africa
}

\author{
Thomas Panganayi Thondhlana ${ }^{a^{*},}$ Marcos Martinón-Torres ${ }^{b} \&$ Shadreck Chirikure ${ }^{c}$ \\ a Department of Archaeology and Museum Studies, Faculty of Culture and Heritage Studies, Great \\ Zimbabwe University, Masvingo, Zimbabwe \\ b UCL Institute of Archaeology, 31-34 Gordon Square, London WC1H OPY, United Kingdom \\ c Department of Archaeology, University of Cape Town, Rondebosch, Cape Town 7701, South Africa
}

\begin{abstract}
Mining and metallurgy have previously been cited as the sole activities that encouraged the permanent occupation of the agropastorally marginal region conventionally known as the northern Lowveld of South Africa prior to the nineteenth century. Archaeologists have previously documented more than 50 second-millennium AD settlements, associated with extensive evidence of metal production, around Phalaborwa in this region. Archaeometallurgical research was carried out at Shankare Hill, one of these Iron Age settlements with remarkable evidence of metal production, in order to reconstruct the extractive metallurgical activities represented at the site. To achieve this standard archaeological fieldwork procedures together with post-fieldwork laboratory studies were employed. This paper presents both the archaeological and archaeometric results that enabled the reconstruction, in great detail, of the various metal production activities from ore beneficiation to primary smelting and subsequent metal refining processes that took place at Shankare. Iron smelting debris, which significantly differed both microscopically and chemically from copper smelting slags, was documented at middens with exclusive metal production debris, whilst copper production debris, which included mostly crushed furnace slag and secondary refining ceramic crucible fragments, was confined to low density scatters and domestic middens. The Palabora Igneous Complex, whose unique ore signature is well documented in the geological literature, was identified as the source of both the copper and iron ores smelted at Shankare. Beyond the technological reconstruction, the results are used to discuss the role of metal production and exchange within the wider southern African archaeological context.
\end{abstract}




\begin{abstract}
ABSTRAIT
Les mines et la métallurgie ont été présentées comme les seules activités qui encouragèrent l'occupation permanente de la région conventionnellement appelée le 'lowveld septentrional' d'Afrique du Sud avant le dix-neuvième siècle, car il s'agit d'une région marginale pour les agropastoralistes précoloniaux. Les archéologues ont déjà documenté plus de 50 gisements du deuxième millénaire ap. J.-C., associés à de nombreuses preuves de la production de métaux, autour de la ville actuelle de Phalaborwa. Des recherches archéométallurgiques ont été effectuées à Shankare Hill, l'un de ces gisements de l'Age du Fer qui offre des preuves remarquables de la production de métaux, dans le but de reconstituer les activités extractives métallurgiques qui y furent effectuées. Afin d'y parvenir, on a employé les procédures de fouille archéologique classiques ainsi que des études de laboratoire suite aux travaux de terrain. Cet article présente les résultats archéologiques et archéométriques qui ont permis la reconstruction, dans les moindres détails, des différentes activités de production de métal qui eurent lieu à Shankare Hill, du minerai jusqu'à la première fusion et aux procédures de raffinage du métal. Les débris de fonte du fer, qui diffèrent significativement des scories de fonte du cuivre à la fois au microscope et chimiquement, furent identifiés dans les amas constitués exclusivement de débris de la production de métaux, alors que les débris de la production de cuivre, qui comprenaient principalement des scories pilées de fourneau et des fragments des creusets en céramique pour le raffinage secondaire, sont présents à faible densité et sont limités aux tertres domestiques. Le complexe igné de Palabora, dont la signature de minerai unique est bien documentée dans la littérature géologique, a été identifié comme la source des minerais à la fois de cuivre et de fer qui furent fondus à Shankare Hill. Au-delà de la reconstruction technologique, les résultats sont utilisés pour examiner le rôle de la production et de l'échange de métaux dans le contexte général archéologique d'Afrique australe.
\end{abstract}

\title{
KEYWORDS
}

archaeometallurgy, extractive metallurgy, black copper, iron smelting, Phalaborwa, South Africa

\section{INTRODUCTION}

Mining and metallurgy have previously been cited as the sole activities that encouraged the permanent occupation of the agropastorally marginal region conventionally known as the northern Lowveld of South Africa prior to the nineteenth century. Archaeologists have previously documented more than 50 second-millennium AD settlements, associated with extensive evidence of metal production, around Phalaborwa in this region. Archaeometallurgical research was carried out at Shankare Hill, one of these Iron Age settlements with remarkable evidence of metal production, in order to reconstruct the 
extractive metallurgical activities represented at the site. To achieve this standard archaeological fieldwork procedures together with post-fieldwork laboratory studies were employed. This paper presents both the archaeological and archaeometric results that enabled the reconstruction, in great detail, of the various metal production activities from ore beneficiation to primary smelting and subsequent metal refining processes that took place at Shankare. Iron smelting debris, which significantly differed both microscopically and chemically from copper smelting slags, was documented at middens with exclusive metal production debris, whilst copper production debris, which included mostly crushed furnace slag and secondary refining ceramic crucible fragments, was confined to low density scatters and domestic middens. The Palabora Igneous Complex, whose unique ore signature is well documented in the geological literature, was identified as the source of both the copper and iron ores smelted at Shankare. Beyond the technological reconstruction, the results are used to discuss the role of metal production and exchange within the wider southern African archaeological context.

The inception of metallurgy in southern Africa was characterised by smallscale production, as extrapolated from the modest amounts of metallurgical debris and metal artefacts (of both iron and copper) dating to the first millennium AD (Miller 2001a). The significant increase in the scale of metal production that started during the early second millennium coincided with major transformations in the spheres of economics, religion and politics leading to the development of the earliest forms of cities and state systems. Many scholars hence believe that the production of metals contributed significantly to these developments (Herbert 1996RIDCIT0045; Calabrase 2000; Chirikure 2007). Thus, Miller (2002: 1083) declared that metal production forms a key element in our comprehension of the history of the southern African sub-continent. We too are of the conviction that metallurgy formed a critical element of pre-colonial African societies such that, if not considered in detail, our comprehension of the history of southern Africa will remain at best incomplete, and at worst sketchy.

Unfortunately, our information on pre-colonial extractive copper technologies in southern Africa remains sketchy when compared to iron production (Miller 2003RIDCIT0074). Numerous pre-colonial copper mines reported in the region bear witness to the importance of copper in traditional African value systems (Summers 1969; Evers and van der Berg 1974; Hanisch 1974; Bisson 1976; Friede 1980; Mason 1982). However, documented ethnographic information on copper smelting is scant because such activities were often kept a secret from European settlers and other foreign observers (Bisson 2000: 84; Hall et al. 2006: 31). In the absence of documented ethnographic information, archaeological approaches become the only avenue available to us to salvage information about these extinct technologies. Unfortunately, there seems to 
be a perplexing lack of copper smelting evidence in the region (Summers 1969: 105; Herbert 1984: 26; van Waarden 2014). Most of the information about pre-colonial copper production in Sub-Saharan Africa comes from routine metallographical studies that have been carried out on museum and private collections (e.g. Craddock 1985; Craddock and Picton 1986; Craddock et al. 1997; Miller 2002; Thondhlana and Martinón-Torres 2009). Systematic fieldwork and dedicated laboratory work is the key to understanding early copper production in the region. It is against this background that we decided to systematically search and document evidence of copper production around Phalaborwa. However, during our investigations we also documented iron smelting debris, which became invaluable comparative material that we also present in this paper.

This paper reports on the results gathered during two fieldwork seasons and from subsequent laboratory analyses of metallurgical debris and products from Shankare Hill. Our investigations aimed to come up with a highresolution reconstruction of metal production stages, from raw material procurement to the final product. The rationale for choosing Shankare Hill in this study was based on two main considerations. Firstly, previous scholars had reported the presence of extensive copper and iron production debris at the site (Mason 1986; Pistorius 1989). Secondly, Shankare is one of the few pre-colonial settlements around Phalaborwa that was spared from destruction during recent commercial mining activities. Previously reported archaeological sites such as Lolwe, Nareng, Nagome, Ghoenkop, Eskom and Molotho (Figure 1) have since vanished under the tailings of modern mining activities (van der Merwe and Scully 1971; Plug and Pistorius 1999; Thondhlana 2012).

\section{Brief background to the northern Lowveld}

Pioneer European hunting parties, explorers, mineral prospectors, missionaries and settlers, together with their pack animals, who had an encounter with the northern Lowveld, were severely affected by sleeping sickness, malaria, black water fever and bilharzia. The northern Lowveld was subsequently dubbed the 'Fever Flats' and 'Whiteman's Grave' (Cartwright 1974; Stevenson-Hamilton 1974). For these pioneers the region was a death trap that was unhealthy for human habitation and livestock rearing (Plug and Pistorius 1999). The absence of settlements that conform to the Central Cattle Pattern (CCP) around Phalaborwa has been used by archaeologists to argue that the area's pre-colonial inhabitants placed little value on livestock rearing (Huffman 1986a, 1986b; Plug and Pistorius 1999). On the other hand, the region receives erratic rains, with an average of $450 \mathrm{~mm}$ of rainfall per year, which scholars believe also hindered agricultural activities. However, this region is richly endowed with geological deposits with ores that were important to pre-colonial peoples. Throughout the second millennium AD this 
presumably agropastoral marginal region, particularly around Phalaborwa, was thus populated by renowned miners and metalworkers (Mason 1986; Miller et al. 2001).

Archaeometallurgical research requires a firm grip of the geology of the research area. Major geological events that resulted in the deposition of copper and iron together with other minerals were established from the geological literature (Palabora Mining Company Limited Mine Geological and Mineralogical Staff 1976; Ericksson 1984; Viljoen and Reimold 1999; Groves and Vielreicher 2001). However, space cannot allow us to give a detailed outline of the geological events and mineralogical characteristics of important ore deposits in this paper (see Miller et al. 2001; Thondhlana 2012). The Palabora Igneous Complex supplied both copper and iron ores to pre-colonial metalworkers within a $25 \mathrm{~km}$ radius of Phalaborwa (van der Merwe and Killick 1979; Miller et al. 2001, 2002). Lolwe Hill, which was destroyed by open pit mining activities that commenced during the 1960s, was the epicentre of the Palabora Igneous Complex. Two geological members belonging to the Palabora Igneous Complex are of great significance in this paper. Firstly, the foskorite member, which contains magnetite-apatite-olivine together with sulphidic copper mineralisation, was an important source of the iron ores that were used around Phalaborwa. Note that the magnetite ores in this member are titaniferous and contain up to $8.0 \%$ by weight $\mathrm{TiO}_{2}$ (Miller et al. 2001). Secondly, enclosed inside the foskorite is the central carbonatite member, which also contains copper and magnetite mineralisations, among other minerals. Contrary to the magnetite ores in the foskorite member, the magnetite associated with the central carbonatite contains significantly less titanium. The geological literature also highlights the fact that the rocks/minerals from the central carbonatite member are notably undersaturated (i.e. are silica free) (Russell et al. 1954; Groves and Vielreicher 2001).

\section{Previous investigations at Shankare Hill}

Shankare Hill (Map Sheet: South Africa 1:50 000 Sheet 2331CC Phalaborwa; $23^{\circ} 58^{\prime} \mathrm{S}, 31^{\circ} 09^{\prime} \mathrm{E}$ ) is composed of two prominent syenite outcrops situated in the extreme northeastern part of Cleveland Game Park, which is privately owned by the Palabora Mining Company (PMC). The site is located within a 5 $\mathrm{km}$ radius of Lolwe Hill, the presumed source of iron and copper ores. Shankare Hill, previously publicised as Shangaankop, was one of the first Iron Age sites to be targeted for systematic investigations by professionally trained archaeologists in the 1960s (Mason 1965, 1986; Mason et al. 1983). During this period Revil Mason excavated four main features, namely: a threeaperture furnace on the northwestern side (Site 10/64), two ash middens on the terraced platforms (Sites 11/64 and 12/64) and a forge (Site 3/67) (Mason 
1986RIDCIT0068: 112-124). Two uncalibrated radiocarbon dates of $290 \pm 80$ (Y-1766) and $90 \pm 60 \mathrm{BP}(\mathrm{Y}-1769)$ were acquired from charcoal samples from the forge area and an ash midden respectively (Mason 1986: 133). Using the Southern Hemisphere SHCal13 (Hogg et al. 2013) calibration curve, these dates calibrate at 95\% probability to between cal. AD 1458 and 1891 and post cal. AD 1674 respectively. Mason also managed to locate eight 'smelting furnace' instalations together with several domestic refuse middens. Unfortunately, no hut floor remains were documented during the 1960s fieldwork.

Subsequent archaeological investigations at Shankare were carried out by Julius Pistorius (Pistorius 1989). He excavated two terraced platforms (SHA1T8 and SHA1T18), a domestic midden (SHA3) and a copper smelting furnace (SHA2M1). Pistorius' work extended the chronology of occupation and metal production activities at Shankare Hill back to the terminal first/early second millenium AD. The copper smelting furnace was radiocarbon dated to $890 \pm$ 50 BP (Pta-4443; cal. AD 1046-1278), which makes it the earliest known in situ evidence of copper smelting around Phalaborwa (Pistorius 1989). Copper smelting furnaces at Molotho and Matsepe (Serotwe), also found around Phalaborwa, were radiocarbon dated at least five centuries later than the Shankare furnace (Stuiver and van der Merwe 1968: 58; van der Merwe and Scully 1971: 183; Evers and van der Merwe 1987: 90). Recent occupation history, gathered from oral traditions, suggests that Shankare Hill was later inhabited by the renowned Maseke-Malatji copper smelters and smiths (Pistorius 1989; Plug and Pistorius 1999: 160-164).

Mason and Pistorius concur that metal production was a major economic activity at Shankare Hill. Pioneering archaeological investigations at Shankare were thus successful in establishing the basic chronology of human habitation and smelting activities. These studies, which combined archaeological and ethnohistorical approaches, highlighted the complex settlement history spanning at least a millennium at Shankare Hill (Mason 1986; Pistorius 1989). However, limited analytical work was carried out on the metallurgical debris from Shankare, thereby motivating our own detailed study.

\section{Archaeological surveys and excavations: approaches and results}

Multi-stage intra-site survey techniques were employed in the course of two archaeological field seasons at Shankare (following Schiffer et al. 1978; Redman 1987; Orton 2000; Banning 2002). Reconnaissance surveys were carried out in September 2009, while intensive surveys were conducted during August 2010 archaeological field season. Both fieldwork campaigns coincided with the dry winter season to take advantage of sparse vegetation cover that offered better visibility of surface. The surveys involved the systematic visual inspection and pedestrian traversing across Shankare Hill 
and the adjacent lowland. During the surveys, the location of metal production related activity areas was captured with a handheld GPS system (Figure 2). Activity areas in the form of discrete clusters of surface artefacts or certain features were preliminary classified as domestic middens, smelting and smithing, slag/ore crushing or refining precincts pending laboratory investigations.

Past cultural activities documented at the site included terraced platforms, ruined stone walls and clusters of backed clay. Circular foundations of adobe structures that usually represent huts in Iron Age contexts in southern Africa (Huffman 2007) were not documented at Shankare Hill. Large domestic ash middens, rock boulders with dolly holes, stone cairns, several scatters of metallurgical debris in the form of ore samples, tuyères and slag were recorded in the undulating plain on the northern part of Shankare Hill. Rock boulders and portable anvils with dolly holes together with dimpled hammerstones were preliminarily classified as evidence of either ore beneficiation and/or slag crushing. However, our efforts to locate in situ smelting furnaces of the kind documented by Mason during the 1960s were fruitless. Unfortunately, advanced subsurface detection methods, invasive or non-invasive, which could have helped us to locate the furnaces, were not readily available.

Two exploratory excavation trenches (SHASH1 and SHAM1) were sunk at Shankare Hill during the second field season. The trenches were subdivided into one by one metre excavation units that were excavated in arbitrary $10 \mathrm{~cm}$ spits levels downward from the surface. Trench SHASH1 $\left(23^{\circ} 58^{\prime} 07^{\prime \prime} \mathrm{S}, 31^{\circ} 09^{\prime}\right.$ $\left.44^{\prime \prime} \mathrm{E}\right)$ as placed on top of a high concentration of metallurgical debris located on the northeastern foothill of Shankare Hill. This trench yielded slag, tuyère pieces, baked clay (presumably from a furnace wall), isolated artefacts, hammerstones and a few fragments of domestic pottery at the bottom. This trench produced $45 \mathrm{~kg}$ of slag with a potential excavation density score of 75 $\mathrm{kg} / \mathrm{m}^{3}$. The charcoal impressed slag and heavily bloated tuyère tips from this trench were interpreted in the field as evidence of primary smelting activities as opposed to secondary refining. The evidence from this trench was subsequently established to be by-products of iron smelting after archaeometric analysis.

Trench SHAM1 $\left(23^{\circ} 58^{\prime} 05^{\prime \prime} \mathrm{S}, 31^{\circ} 09^{\prime} 43^{\prime \prime} \mathrm{E}\right)$ was sunk on a large domestic midden with limited metallurgical debris on its surface (Figure 3 ). The midden offered an opportunity to recover metal production debris together with diagnostic ceramics and other datable materials. Domestic ceramics were by far the most ubiquitous artefact category from trench SHAM1. Diagnostic ceramics sherds with necked jars with herringbone, punctates and crosshatched incision motifs (Figure 4) exclusive to Kgopolwe pottery dating between the tenth and thirteenth centuries $A D$ around Phalaborwa were retrieved from this trench (Evers and van der Merwe 1987; Simon Hall, pers. 
comm. 2010). These dates were corroborated by radiocarbon determinations of charcoal samples from this trench. Three age determinations of $830 \pm 30 \mathrm{BP}$ (Beta-306714), $840 \pm 30$ BP (Beta-306715) and $1010 \pm 30$ BP (Beta-306716) were obtained (Thondhlana 2012). These dates calibrate at $95 \%$ to cal. AD 1204-1284, 1189-1279 and 1021-1152 respectively. This trench also yielded large quantities of faunal remains together with evidence of metal production albeit in smaller quantities. The metallurgical debris inventory included largely crushed slag fragments, vitrified crucible fragments, tuyère fragments, copper prills and fragments of copper objects. The total weight of the slag from the five excavation units at SHAM1 was $2.44 \mathrm{~kg}$ with an excavation density score of approximately $1 \mathrm{~kg} / \mathrm{m}^{3}$. Ornaments from this trench included 108 shell beads manufactured from locally available raw materials. Four glass beads and two Conus shells, presumably obtained via merchants operating along the Indian Ocean coast, were also retrieved. An unmarked human burial $\left(23^{\circ} 58^{\prime}\right.$ $05^{\prime \prime} \mathrm{S} ; 31^{\circ} 09^{\prime} 43^{\prime \prime} \mathrm{E}$ ) was unexpectedly encountered during the excavation unit B8 at trench SHAM1. However, because of ethical considerations we closed this burial before it was fully exposed and were thus unable to establish the complete picture of the accompanying grave goods.

\section{Applied analytical methods}

Selected samples of metallurgical debris and metal artefacts retrieved from Shankare, mainly those suspected to be products of copper production, were subsequently subjected to analytical characterisation at the Wolfson Archaeological Science Laboratories, UCL Institute of Archaeology, London. Two types of samples were employed: polished-cross sections mounted in epoxy resin for microscopy and microanalysis and pressed powder pellets (15 $\mathrm{g}$ with a small amount of wax) for bulk chemical analysis.

Polished blocks were used to gather information that included optical properties, morphology and the relative abundance of phases and minerals with the aid of optical and electron microscopy. A Leica optical microscope equipped with a digital camera was used for optical microscopy. Complimentary imaging and chemical analysis was carried out with a scanning electron microscopy coupled with energy dispersive spectrometry (SEM-EDS). A Hitachi S-3400N instrument equipped with an INCA Oxford X-ray energy dispersive spectrometer was used to gather phase compositional data, as well as an approximation of 'bulk' compositions by area analyses. Pressed pellets were also used to gather bulk chemical results employing $X$-ray fluorescence spectrometry (XRF). To conduct XRF analysis a Spectro X-Lab Pro 2000 instrument with secondary targets to polarise the primary $X$-rays was used. Silica-rich and iron-rich control materials were used to monitor accuracy and precision. 


\section{Archaeometallurgy and analytical results}

Preliminary fieldwork observations had to be complemented with laboratory analysis in order to establish further the relationship between the presumed ores, slags, technical ceramics and metals. This section of the paper presents the results based on the laboratory work carried out with optical microscopy, together with the phase and bulk composition analytical approaches outlined above.

\section{Presumed ores}

An in-depth understanding of the mineralogy and chemistry of archaeological ore samples is crucial in the subsequent reconstruction of the smelting technology. One hundred and twenty-five presumed copper and iron ore samples were retrieved from Shankare. There are no known geological deposits or outcrops of copper mineralisation or iron ores around the site and its immediate environs. Hand-specimens of presumed ore samples were classified into three major groups based on their external appearance and response to magnetic tests. The first group was composed of non-magnetic small chips of soft, light green and blue copper carbonates. The second group had highly magnetic irregular chunks of hard, solid and black magnetite. The third group is represented by magnetite chunks visibly stained by specks and veinlets of green copper compounds, which indicate the unique co-existence of copper and iron in the geological deposit previously noted by other scholars (Miller and Killick 2004: 29).

Only fourteen presumed ores, mostly with visible copper staining, were deliberately targeted for further examination to establish their chemistry and detailed mineralogy, together with phase and bulk compositional analysis. We did not concentrate on iron ore samples because these had been previously characterised in great detail by other scholars (van der Merwe and Killick 1979; Killick and Miller 2014). The host rock for the copper minerals was observed as magnetite $\left(\mathrm{Fe}_{3} \mathrm{O}_{4}\right)$, fluorapatite $\left(\mathrm{Ca}\left(\mathrm{PO}_{4}\right)_{3} \mathrm{~F}\right)$, calcium carbonate $\left(\mathrm{CaCO}_{3}\right)$ and occasionally siliceous minerals. Microscopically, these presumed ores were dominated by secondary oxidised minerals with some residual sulphide inclusions, such as chalcopyrite $\left(\mathrm{CuFeS}_{2}\right)$, chalcocite $\left(\mathrm{Cu}_{2} \mathrm{~S}\right)$ and barite $\left(\mathrm{BaSO}_{4}\right)$ (Figure $5 \mathrm{a}$ and Figure $5 \mathrm{~b}$ ). Isolated rare earth oxides and phosphate inclusions $\left(\mathrm{La}_{2} \mathrm{O}_{3}, \mathrm{Ce}_{2} \mathrm{O}_{3}, \mathrm{Pr}_{2} \mathrm{O}_{3}\right.$ and $\left.\mathrm{Nd}_{2} \mathrm{O}_{3}\right)$ were occasionally encountered. Bulk chemical characterisation of these presumed ores was obtained systematically using area scans with SEM-EDS (Table 1). The copper oxide content in the presumed ores samples ranged from 8-60 wt \%, while $\mathrm{FeO}$ ranged from as little as $0.3-63 \mathrm{wt} \%$. The suite of presumed ore samples analysed were significantly under-saturated (i.e. silica free) and thus consistent with information provided in the geological literature, with very low levels of $\mathrm{TiO}_{2}$. None of these presumed ore samples contained detectable levels of zinc, tin 
or arsenic. To sum up, the presumed ore samples from Shankare were identified as copper carbonates, namely malachite and occasionally azurite, which occurred together with magnetite, fluorapatite and calcium carbonate.

\section{Smelting slags}

Slags when properly investigated can be the most informative source about extinct extractive metal technologies (Bachmann 1982). The slag pieces from Shankare had an average weight of 15 grams each, much less than slag blocks weighing up to $100 \mathrm{~kg}$ each documented from archaeological sites in East Africa (e.g. Humphris et al. 2009). Note that the slags from East Africa were produced in slag pit furnaces that differed significantly from the low shaft furnaces typically found around Phalaborwa. Slag typologies based on diagnostic external appearances have been employed previously to classify archaeological slags in southern Africa (Friede et al. 1982; Chirikure and Rehren 2004, 2006; Greenfield and Miller 2004; Miller and Killick 2004). Some of these classes include tap slag, flow slag, furnace slag and smithing slags. Most of the slags from Shankare are irregular in shape and charcoalimpressed and thus fit well under the category of furnace slags (Figure 6a). However, it is clear that some of these slags were further processed, by crushing, after smelting (Figure 6b). The crushed slag samples were occasionally found together with dimpled hammer stones and rock surfaces with peculiar dolly holes. It was very difficult to discriminate copper from iron smelting slags macroscopically. As such, 35 slag pieces were subjected to detailed analytical work, which allowed us to distingush iron from copper smelting slags.

Eight weakly magnetic slags from trench SHASH1 were identified as iron smelting slags with the aid of microscopic and chemical analyses. Microscopically, these iron furnace slags fall into two sub-groups. The first group is dominated by blocky olivines, angular ulvospinels with occasional wüstite dendrites or globules together with metallic iron particles (Figure 7a). The second group was represented by slag samples dominated by wüstite dendrites with occasional interstitial glass and metallic iron particles (Figure $7 b)$. The angular shape of the metallic iron particles $(<20 \mu \mathrm{m}$ in size) suggests that they were reduced in their solid state. Bulk chemical results indicated that the three principal oxides in these iron slags were $\mathrm{FeO}(33-49 \mathrm{wt} \%), \mathrm{SiO}_{2}$ (27-30 wt \%) and $\mathrm{CaO}$ (10-15 wt \%) (Table 2 and Table 3). The iron smelting slags also contained four other major oxides, namely $\mathrm{TiO}_{2}$ (4-9 wt \%), $\mathrm{Al}_{2} \mathrm{O}_{3}$ (56 wt \%), $\mathrm{MgO}\left(4-5\right.$ wt \%) and $\mathrm{K}_{2} \mathrm{O}(2-3 \mathrm{wt} \%)$. The relatively high level of $\mathrm{TiO}_{2}$ is in agreement with the dominance of ulvospinels in most iron slags and in turn coherent with the high $\mathrm{TiO}_{2}$ reported for some of the magnetite from the Palabora Igneous Complex (Killick and Miller 2014). The predominance of wüstite and the presence of metallic iron are indicative of strongly reducing 
conditions, consistent with iron production rather than copper smelting (Morton and Wingrove 1969, 1972; Miller and Killick 2004).

Twenty-seven strongly magnetic slag samples excavated from trench SHAM1 (domestic midden) and surface collected from other slag scatters were identified as copper smelting slags with the aid of microscopy and chemical investigations (Figure 2). These copper smelting slags were strongly magnetic as a result of the visible unreacted magnetite minerals and secondary high temperature magnetite spinels. This confirms the observation that magnetism is not always a reliable criterion for distinguishing iron from copper production slags (Miller and Killick 2004: 26). Microscopically, copper smelting slags were heterogeneous and dominated by blocky fayalite olivines, magnetite spinels with occasional copper prills and significantly less interstitial glass (Figure 8). Fayalitic slags are consistent with reducing atmosphere typical of smelting rather than melting processes, but magnetite spinels $\left(\mathrm{Fe}_{3} \mathrm{O}_{4}\right)$ are much more frequently associated with copper smelting rather than iron smelting (Bachmann 1982; Miller and Killick 2004), as they denote an atmosphere that is sufficiently reducing for the formation of metallic copper, but not of iron. Ulvospinels documented in the iron smelting slags were not documented in the copper slags, indicating that titanium free ores were used for copper smelting. Entrapped spherical copper prills, with diameters ranging from a few $\mu \mathrm{m}$ up to $2 \mathrm{~mm}$, which contained impurities such as sulphur and iron, were documented during SEM-EDS spot analyses. Exsolved iron and sulphide inclusions inside these copper prills were further documented with optical microscopy (Figure 9). The documentation of ferruginous copper or 'black copper' prills further strengthens our identification of these slags as smelting products. Although globules of copper sulphide inclusions were recorded in some of these copper prills, they cannot be interpreted as positive evidence of the systematic use of sulphidic ores as they may simply denote the residual presence of sulphides in predominantly oxidic ores.

The most conspicuous feature of the copper smelting slags from Shankare, however, is the notable abundance of residual or unreacted minerals in the form of magnetite, fluorapatite and quartz (Figure 10 and Table 4). The unreacted materials provided valuable information about the nature of the charge that went into the copper smelting furnace. Residual chalcopyrite was documented inside a copper smelting slag sample SHAMK7(1), but this does not suggest the systematic use of sulphidic copper ores at Shankare. Bulk chemical analysis with SEM-EDS shows that the three principal oxides are $\mathrm{SiO}_{2}$ (29-51 wt \%), FeO (6-45 wt \%) and $\mathrm{CaO}$ (8-28 wt \%) (Table 5). There are striking differences between the bulk chemical composition of copper and iron smelting slags from Shankare. Firstly, $\mathrm{TiO}_{2}$, one of the major oxides in iron smelting slags, does not exceed $1.0 \mathrm{wt} \%$ in copper smelting slags. Secondly, one of the major oxides in copper smelting slags $\mathrm{P}_{2} \mathrm{O}_{5}$ is almost absent in the iron smelting slags (Figure 11). Finally, copper smelting slags are significantly 
enriched in $\mathrm{CaO}$ compared to iron smelting slags. Apatite is the likely source of enhanced levels of $\mathrm{CaO}$ and $\mathrm{P}_{2} \mathrm{O}_{5}$ reported in the copper smelting slags from Shankare.

The analytical results of slag sample SHA1NWL were rather peculiar. Macroscopically, this slag had red exterior colour with patches of green corrosion products. Iron phosphide prills with an average of $18.3 \mathrm{wt} \%$ phosphorus, $80.5 \mathrm{wt} \%$ iron and $1.2 \mathrm{wt} \%$ copper were entrapped inside this sample. An iron phosphide metal fragment with up to $12 \%$ phosphorus was previously recovered from the archaeological contexts of Phalaborwa (Miller et al. 2001: 409). It was not easy to assign this slag sample to either iron or copper smelting, but iron phosphide prills documented in this sample further highlight the exploitation ores with phosphorus-rich apatite. The complex ore bodies that were exploited around Phalaborwa would occasionally result in the production of odd metals and alloys that were probably not useful. Elsewhere slag entrapped iron phosphide prills have been interpreted as unwanted speiss and by-products of copper smelting (Thorton et al. 2009).

To summarise, the analytical results obtained from Shankare slags demonstrated that both bloomery iron and copper smelting were practised at the site. Copper resulting from the smelting process was highly ferruginous and thus required further refining under less reducing conditions to get rid of both iron and sulphur impurities. Crucible fragments linked to this refining process were recovered mostly from the domestic midden where we positioned trench SHAM1.

\section{Technical ceramics}

Extractive metallurgical processes inevitably required technical ceramics in the form of furnaces, tuyères and crucibles. Dedicated analytical work on these technical ceramics can provide vital information about metal production or refining processes (see Freestone and Tite 1986; Freestone 1989; Rehren 1999, 2003; Martinón-Torres and Rehren 2002, 2009; Bayley and Rehren 2007). At least 74 slagged crucible fragments were recovered during the excavations and systematic surface collection processes at Shankare. Crucibles could be employed for primary smelting, while in some cases they were employed to refine or to alloy metals (Rehren 2003; Bayley and Rehren 2007). Although systematic methods of analysing technical ceramics are well developed in Europe, analyses of technical ceramics in southern Africa have been sporadic (Friede and Steel 1975; Maggs and Miller 1995; Miller 2001; Hall et al. 2006; Chirikure et al. 2015). The main objective of carrying out analytical work on these slagged technical ceramics was to establish their role in metallurgical processes. There was a possibility that they were employed to melt, consolidate and alloy non-ferrous metals (Miller 2010) or as 'crucible smelting furnaces' as previously suggested by Friede and Steel (1975: 226) and Miller (2002: 1102). 
Crucible fragments from Shankare were no doubt exposed to extremely high temperature regimes because of the evidence of vitrification. Unfortunately, the fragmentary nature of these sherds makes it impossible to establish their original form and size. Metallurgical residues in the form of slag lining and copper prills together with extensive vitrification were restricted to the concave part, i.e. the presumed interior, of these crucible sherd. The analytical results that we obtained from the crucible fabric and metallurgical debris are presented in Tables 6 and 7.

The ceramic fabric of these crucibles contains quartz and feldspar grains that are mostly sub-rounded and poorly sorted. The high to low temperature gradient in the ceramic fabrics suggests that the source of heat was inside the vessels. Bloating and rounded porosity reaching up to $200 \mu \mathrm{m}$ was limited to the innermost parts of the ceramic sherds. With the restriction of vitrification to the concave side we surmised that firing was from within the crucible and controlled from above rather than from the exterior (Muller et al. 2004).

Slag or vitrified linings together with metal prills that were attached to the crucible fragments also provide invaluable information. In this case, the microstructure and chemical composition of the slag linings are consistent with a process of crucible metal melting rather than smelting. These slag linings contained a significantly high lime content (CaO: 16-26 wt \%) compared to the crucible ceramic fabrics, which suggests a contribution from fuel ash from charcoal that was charged inside the crucible. The metal prills attached to these crucible fragments differed significantly from the copper prills entrapped in the copper smelting slags discussed above. Metallographic analysis, which was complemented by SEM-EDS analysis of these prills, highlighted the fact that they were pure copper with cuprite inclusions, suggestive of fairly oxidising conditions (Figure $12 \mathrm{a}$ and Figure 12b) and incompatible with the reducing environment required for smelting and indeed recorded in the iron-rich copper prills in the smelting slags described above. The composition of the metal prills and metallurgical debris associated with these crucible fragments also rules out the practice of bronze alloying or brass melting. We thus conclude that the crucibles were used to refine and consolidate the highly ferruginous copper prills that were retrieved after the crushing of copper smelting slags presented above. The re-melting of raw copper in oxidising conditions was meant to oxidise exsolved iron impurities and expel sulphur.

\section{Copper artefacts, prills and fragments}

Only 14 copper artefacts in the form of amorphous articles, bangle fragments, short wires, prills and sheets with a total weight of 58 grams were retrieved from Shankare during the two fieldwork seasons (Figure 13). Plano-convex ingots, previously recovered around Phalaborwa (Miller 2002), were not 
found at Shankare. Of the six metal artefacts that were prepared for metallographic analyses only SMB22(3) copper contained copper sulphide inclusions, whilst the rest [SMB21(2), SMB26(2), SMB81(1), SSC(1) and SSC(2)] had cuprite inclusions. Sub-spherical prills similar to SMB22(3) were previously interpreted as unrefined primary smelting products (Miller 2001: 87; Miller 2002: 1102). Sulphide and exsolved iron inclusions prevalent in the copper prills entrapped inside the copper smelting slags from Shankare were absent in the finished or semi-finished metal articles. Instead, the major impurity was oxygen that formed a network of cuprite surrounding the dendritic copper alpha phase. The bulk chemical characterisation of the artefacts with SEM-EDS shows that they are largely pure copper with oxygen as an impurity. Such chemistry is expected when relatively pure and high-grade ores are employed. However, we argued above that the copper ores were neither pure nor highgrade and thus conclude that there was thorough secondary refining of the primary smelted copper at Shankare. The artefacts are therefore consistent with the crucible assemblages. Typical copper alloy additives, namely tin, arsenic and zinc, were not detected at Shankare.

\section{Discussion}

The surveys and excavations at Shankare provided the much needed baseline information about the extant socio-economic context in which metal production activities took place. Such information cannot be obtained using archaeometric data or approaches alone. Before we discuss the technical aspects of extractive metallurgy that we established at Shankare we wish to consider some issues of broader archaeological and historical interest. Based on our fieldwork we observed that of the several mundane activities documented at Shankare metal production was the main economic activity. Metal production and working activities were represented by scatters of slag found together with presumed ores, tuyères, technical ceramics, dimpled hammer stones, dolly holed boulders and anvils. However, the modest amount of metal artefacts retrieved from Shankare tempts us to suggest that the finished metal products were taken elsewhere for use. The production of metals at Shankare emerged during a period associated with significant social, cultural, economic and political changes in southern African archaeology. Firstly, for the first time in this region archaeologists find evidence of classbased societies together with increased centralisation of political power to create earliest forms of urbanism and states (Pikirayi 2001; Mitchell 2002; Huffman 2007). Secondly, there is also documentary and archaeological evidence suggesting serious commercial interaction between some southern African communities and overseas markets during this period (Pwiti 1991; Mitchell 2005; Killick 2009a; Chirikure 2014). Southern African communities were producing ivory, animal skins and gold for overseas markets in return for 
cloth, seashells, glass beads, oriental ceramics and copper alloy objects. Prior to these developments most communities in southern Africa appear to have been largely self-sufficient subsistence farmers. who nevertheless regularly engaged in inter-village exchange due to the unequal distribution of essential resources like metals and salt (Fagan 1969). Some scholars are of the opinion that the production of metal played a critical role in social and political evolution (Rowlands 1971; Herbert 1996; Calabrese 2000; Chirikure 2007). It is thus important to discuss the social role and status of metal producers at a regional scale.

Recent ethnographic evidence from Sub-Saharan Africa is rather ambiguous when it comes to the role or status of metal producers in their immediate societies and beyond. In some instances indigenous metal workers are viewed as highly privileged, wealthy specialists and founders of important pre-colonial chiefdoms and states (Chirikure 2010, 2015) while in some societies they have a low status (Haaland 2004; Haaland et al. 2004). The available ethnohistoric information suggests that the social organisation and metal production practices found in Sub-Saharan Africa were never uniform in space and time. In the absence of ethnographic information dating to the occupation of Shankare Hill we have to rely on the archaeological record to establish the status and role of the metal producers. We have already indicated that metal production activities at Shankare coincided with intensified interaction between southern Africa and the Indian Ocean world. This interaction brought with it many imports such as glazed ceramics, seashells, cloth and glass beads (Garlake 1968; Miller 2002; Wood 2011). Archaeological sites contemporary to Shankare in the Shashe-Limpopo Basin such as Mapungubwe, Mapela and K2 have yielded substantial quantities of these exotic goods (Huffman 2005; Chirikure 2014). Exotic goods together with gold and elaborate drystone walls have frequently been interpreted there as high-status markers or icons (Miller et al. 2000; Pikirayi 2001; Killick 2009b), although some dispute using exotic goods alone as evidence of high-status (Chirikure 2014). If a significant frequency of exotic goods is considered as a universal hallmark of wealth or status, then the evidence from Shankare suggests that the metal workers living there were poorer. Our excavations at Shankare, although superficial in their area coverage, yielded only four glass beads and two seashells, while we did not record any imported ceramic sherds of the kind found at other contemporary élite sites to the north of the northern Lowveld. Elsewhere, Bronze Age copper producers in the Mitterberg region, Austria (Shennan 1998) and Iron Age copper producers in the Khao Wong Prachan Valley in Thailand (Pryce et al. 2010) have also been interpreted as having a low social standing, despite the fact that they were producing metals that were in high demand in neighbouring farming communities. One plausible explanation for this low recovery of exotic items is that the second-millenium occupants of Shankare had limited or less formalised contacts with Indian Ocean traders. 
We thus concur with other scholars who have concluded that pre-colonial metal production around Phalaborwa responded largely to regional demands rather than to contemporary maritime commerce (Miller et al. 2001; 2002). Nineteenth-century ethnographic evidence suggests that Phalaborwa metal workers heavily depended on their agropastoralist neighbours for foodstuffs, which they exchanged for both ores and metals (Miller et al. 2002). Since these foodstuffs are perishable little evidence of them can be expected to survive in the archaeological record. We thus tentatively surmise that long distance trade or exchange would have played a peripheral role in the day to day lives of early second-millennium AD metallurgists at Shankare.

The archaeometric results of extractive metallurgical debris from Shankare allowed us to establish the production cycle of both copper and iron. Raw materials such as ores have a direct impact on the extractive technology, byproducts and final metal products. The smelting slags presented in this paper are typical ferrous silicates. However, a cursory comparison of the mineralogy and bulk chemical data of presumed ore samples and slags highlights some extreme disparities. The presumed ores were very poor in silica, while enhanced silica levels were documented in both copper and iron smelting slags. Silica was likely intentionally introduced to the furnace charge as flux, with some of it obtained from the eroding fabric of furnace walls and tuyeres (David et al. 1989; Miller et al. 2001). The presence of micrometric unreacted mineral fragments in the slags also provided direct evidence of the minerals that went into the furnace charge. Unreacted and partially dissolved apatite, magnetite, quartz and chalcopyrite documented in the copper smelting slags were part of the furnace charge. Apatite is one of the accessory minerals occurring together with copper mineralisations in the Palabora Igneous Complex (Roux et al. 1989: 130). The copper mineralisations in the carbonatite member at Lolwe occurred together with calcite, magnetite and apatite (van der Merwe and Killick 1979: 86). The presence of unreacted minerals inside copper smelting slags thus suggests poor beneficiation and fluxing processes, as well as a furnace charge where the raw materials appear not to have been very well balanced.

Thousands of tonnes of titanium-rich magnetite in the foskorite member were still available for surface collection prior to modern open pit mining at Lolwe Hill (van der Merwe and Killick 1979: 86). On the other hand, titanium-free magnetite ores tainted with copper mineralisations from the central carbonatite required underground mining (Russell et al. 1954: 203). The unreacted magnetite embedded inside the copper smelting slags is consistent with magnetite ores from the central carbonatite. Titanium free magnetite from the central carbonatite would have posed major challenges for the ironsmelters because the magnetite occurred together with copper mineralisations and laborious underground mining. It was impossible to extract iron from magnetite ores from the central carbonatite without spoiling 
the iron metal with copper. Given these challenges we feel strongly that residual magnetite found in the crushed slags has nothing to do with iron smelting. Ubiquitous residual magnetite minerals were also documented in archaeological copper smelting slags from Iron Age sites in the Khao Wong Prachan Valley of Thailand (Pryce et al. 2010). The iron-rich black copper produced in primary smelting could be refined under oxidising conditions to remove iron in the form of dross (Tylecote and Merkel 1985: 7; Merkel 1990: 117), which seems to be consistent with the evidence of crucible refining that we documented at Shankare.

Bulk chemical data obtained from Shankare slags were plotted on the FeO$\mathrm{CaO}-\mathrm{SiO}_{2}$ ternary system to approximate the furnace working temperature (Figure 14). We appreciate the challenges of employing phase diagrams for heterogeneous slags that did not reach a free-flowing state (Friede et al. 1982; Miller and Killick 2004). However, in our case we used SEM-EDS to analyse the well-reacted areas, thus avoiding unreacted mineral inclusions. Apart from $\mathrm{FeO}, \mathrm{CaO}$, and $\mathrm{SiO}_{2}$ the smelting slags from Shankare have additional major oxides in the form of $\mathrm{Al}_{2} \mathrm{O}_{3}, \mathrm{TiO}_{2}, \mathrm{P}_{2} \mathrm{O}_{5}$ and $\mathrm{MgO}$, which would also affect their melting point. Iles and Martinón-Torres (2009) highlight the challenges of using ternary phase diagrams for slags with such complex compositions. As an approximation, we decided to plot the Shankare slags on a FeO$\mathrm{SiO}_{2}\left(+\mathrm{Al}_{2} \mathrm{O}_{3}+\mathrm{TiO}_{2}\right)-\mathrm{CaO}\left(+\mathrm{MgO}+\mathrm{P}_{2} \mathrm{O}_{5}\right)$ ternary system. They plotted well on the pseudowollastonite and wollastorite regions with liquidus temperatures ranging between $1100-1300^{\circ} \mathrm{C}$, save for one outlier (SHA1NWL), which plotted in the higher temperature region above $1400^{\circ} \mathrm{C}$. The presence of exsolved iron in the slag entrapped copper prills, which suggests temperatures in excess of at least $1250^{\circ} \mathrm{C}$, corroborates the information that we extrapolated from the phase diagrams (Cooke and Aschenbrenner 1975RIDCIT0018: Craddock and Meeks 1987; Miller and van der Merwe 1994b: 112). Copper prills with exsolved iron reading between $15 \%$ and $30 \%$ should have formed at temperatures of up to $1400^{\circ} \mathrm{C}$ (Craddock and Meeks 1987: 198). The form and abundance of free iron oxides can provide vital information about the redox conditions (Bachmann 1982: 15; Craddock 1995: 17). Magnetite spinels associated with copper smelting slags will be consistent with moderate redox conditions, while wüstite reported inside iron smelting slags indicate much more reducing conditions (Cooke and Aschenbrenner 1975; Miller and Killick 2004).

Ancient copper usually contains ancillary metals that can be potentially informative about the nature of ores and extractive methods that were used (Pernicka 2004). Sulphidic ores are expected to produce matte prills rich in copper and iron sulphides (Craddock 1995: 149-153). Metallographic investigations of slag-entrapped copper prills in Shankare documented globular inclusions of iron and copper sulphides, but not complete matte prills. Sulphide inclusions have been documented in extractive metal 
technologies that used secondary malachite with residual sulphide minerals (Miller and van der Merwe 1994b: 112; Miller 2002: 1102) and we believe this to be the case here. Exsolved iron associated with copper prills entrapped in copper smelting slags also indicates the use of an iron-rich ore charge, or the addition of an iron oxide flux (Miller and van der Merwe 1994b). The evidence of 'black copper' prills concurs with oral traditions claiming that Phalaborwa ores were difficult to work because they produced highly ferruginous copper (Mamadi 1940; Miller et al. 2001: 409). The high purity of the copper artefacts from Phalaborwa was previously interpreted as evidence of the use of fairly low smelting temperatures and remarkably pure copper ores (van der Merwe and Scully 1971: 182). Our reconstructions do not seem to support these previous conclusions: instead, impure ores were used to produce impure copper, which had to be subsequently refined. We therefore encourage those interested in the reconstruction of extractive metallurgy not to limit their analysis to finished products. Had we relied on metal artefacts alone, we too would have suggested the use of highly pure secondary ores around Phalaborwa, just like our predecessors.

The absence of sizeable copper smelting slag heaps, save for slag scatters and the evidence from trench SHAM1, at Shankare Hill, also deserves some comments. The smelting of high grade secondary copper ores using low temperatures in a 'slagless' solid-state copper extraction processes has been used explain the scarcity of copper production debris elsewhere (Küsel 1974: 247; Craddock 1995, 2009; Craddock and Craddock 1996: 61). However, the evidence that we obtained from Shankare suggests otherwise. Unreacted minerals such as magnetite, quartz and apatite rule out the use of pure copper ores, while the rounded copper prills and associated exsolved iron also rule out low temperature and solid-state copper extraction. Copper smelting at Shankare was supposed to produce considerable amounts of slag. The likely explanation for the scarcity of copper smelting slag heaps at Shankare is that the slags were further processed after smelting. Unreacted minerals reported in the copper smelting slags would have increased viscosity, compared to iron slags, making it difficult for the copper prills to liquate through the slag. We propose an 'immature slagging process' (see Bourgarit, 2007) that was followed up with mechanical crushing of slag to retrieve trapped prills, a process conventionally known as the 'prill collection hypothesis' (Maddin, 1988). Rock surfaces and portable anvils with dolly holes together with dimpled hammer stones documented at Shankare were likely used to crush and collect slag entrapped copper prills. The prill collection method was previously documented at other pre-colonial copper smelting sites in southern Africa (Hall et al. 2006: 23).

Prills from the crushed slags were further consolidated and refined inside crucible vessels that were fired from above. The oxidising atmosphere documented on the slag linings and metal prills associated crucible sherds 
likely suggests that the refining process did not involve any furnace with a superstructure. It is most likely that the crucibles were simply placed in a shallow depression in the ground and fired from above, in agreement with the oral traditions of pre-colonial copper workers from Musina in the north of South Africa's Limpopo Province (Stayt 1931: 64; Anderson 2009: 222). Tradition has it that those Musina copper workers actually traced their origin to Phalaborwa (More 1974: 229). We are aware that several plano-convex (bun or dish-shaped) ingots have been recovered from second-millennium contexts around Phalaborwa. Some scholars have interpreted these ingots as products of secondary melting of copper inside clay pots or hemispherical potsherds (Friede 1975: 185; Merkel 1990), while others view them as products of primary copper smelting processes (Miller et al. 2001: 408; Miller 2010: 47). During our fieldwork at Shankare we did not document any planoconvex copper ingots. There was also no evidence of alloying in the form of tin-bronzes, zinc brasses and arsenical copper at Shankare.

Our reconstruction of iron production activities at Shankare, based on titanium-rich iron slags from trench SHASH1, is in agreement with what was documented at several iron smelting sites around the Phalaborwa previously (see van der Merwe and Killick 1979; Miller et al. 2001). These scholars noted that large chunks of high-grade titanium-rich magnetite ores were first crushed to suitable size before they were charged into the furnace. Since these magnetite ores were under-saturated flux, in this case silica-rich quartz, was added. Though the iron smelting process represented the typical bloomery process, northern Lowveld pre-colonial metallurgy was unique, something perfectly captured by other researchers (Miller et al. 2001, 2002; Killick and Miller 2014). Iron extractive technologies that employed high-grade ilmenite-rich black sands have also been documented in a few other cases, for example in Kenya and Nigeria (Ige and Rehren 2003; lles and Martinón-Torres 2009).

\section{Conclusion}

The surveys, excavation and laboratory results presented in this paper provided important insights upon which it was possible to reconstruct past extractive metallurgical processes. The analytical work identified both copper and iron production debris. Copper production involved at least two stages of pyrometallurgical operations under varying redox conditions that we interpreted as smelting and refining processes. At Shankare, copper smelting slags were not recovered from their primary smelting context. Crushed copper smelting slag was found in small quantities, together with crucible fragments and other forms of domestic refuse (SHAM1). On the other hand, primary iron smelting debris does not seem to have been subjected to further processing and was left in situ (SHASH1). This makes evidence of iron production more conspicuous in the archaeological record compared to that for copper 
production. The investigation of spatial patterning of smelting and smithing activity areas has been very informative about some of the sociocultural issues that governed the production of iron in pre-colonial Sub-Saharan Africa. Previous investigations of the spatial patterning of iron smelting activities concluded that such activities were highly ritualised and took place in secluded areas away from habitation sites (e.g. Reid and MacLean 1995; Greenfield and Miller 2004). However, emerging evidence for the spatial configuration of copper smelting and refining precincts suggest significant differences. Archaeological investigations at Madikwe (Grant and Huffman 2007) and Marothodi (Hall et al. 2006; Anderson 2009), both in South Africa, have established that primary copper smelting and related secondary refining furnaces were located close to residential zones. Archaeological evidence of copper smelting and refining at both sites, which included smelting slags, crucible fragments and crucible slags, was also recovered from domestic middens. It was not possible to establish with equal certainty whether the same spatial configuration occurred at Shankare. However, we can tentatively conclude that copper production took place within residential zones because of the association of copper production debris with domestic refuse. On the other hand, iron production debris was dumped in middens with exclusive metallurgical waste material and associated infrastructure. Future work around Phalaborwa should focus more on the spatial patterning of metal smelting and refining activities.

\section{Acknowledgements}

The results presented in this paper formed part of a PhD thesis submitted at the UCL Institute of Archaeology, London (Thondhlana 2012RIDCIT0116). Thomas Thondhlana's studies there were funded by the Institute for ArchaeoMetallurgical Studies (IAMS) and a UCL Dorothy Hodgkin Postgraduate Award (DHPA). We are also heavily indebted to Professor Thilo Rehren, who assisted us in securing the funding for this project. South African Heritage Resources Agency (SAHRA) issued permits that made it possible to carry out archaeological fieldwork (Permit No. 80/09/08/015/50). SAHRA also issued export permits that allowed analytical and invasive sampling to be undertaken in London (Permit No. 80/08/08/012/52). The Palabora Mining Company (PMC) and Palabora Heritage Committee gave us access to conduct archaeological surveys at Shankare Hill. We should like to thank Prof. David Killick, Dr Julius Pistorius, Dr Duncan Miller and Prof. Nikolaas van der Merwe for providing goodwill, support and access to their yet unpublished documents during the course of the research. Without the technical assistance of Kelvin Reeves, Simon Groom and Philip Connolly of the Wolfson Archaeological Science Laboratories our analytical work would have been a mission impossible. We are also grateful to Professor Peter Mitchell and the editors of this journal and two anonymous referees who suggested valuable 
improvements to our earlier drafts

\section{References}

1. Anderson, M.S. 2009. Marothodi: The Historical Archaeology of an African Capital. Northamptonshire: Atikkam Media Limited.

2. Bachmann, H.-G. 1982. The Identification of Slags from Archaeological Sites (Occasional Publication No. 6). London: University of London, Institute of Archaeology.

3. Banning, E.B. 2002. Archaeological Survey. New York: Kluwer Academic/Plenum Publishers. [CrossRef]

4. Bayley, J. and Rehren, T. 2007. "Towards a functional and typological classification of crucibles." In Metals and Mines: Studies in Archaeometallurgy, edited by S. La Niece, D. Hook and P.T. Craddock, 46-55. London: Archetype Publications (in association with the British Museum).

5. Bisson, M.S. 1976. "The prehistoric copper mines of Zambia." PhD diss., University of California, Santa Barbara.

6. Bourgarit, D. 2007. "Chalcolithic copper smelting." In Metals and Mines: Studies in Archeometallurgy, edited by S. La Niece, D. Hook and P.T. Craddock, 3-14. London: Archetype Publications (in association with the British Museum).

7. Calabrase, J.A. 2000. "Metals, ideology and power: the manufacture and control of materialised ideology in the area of Limpopo-Shashe confluence, c. AD 900 to 1300." South African Archaeological Society Goodwin Series 8: 100-111.

8. Cartwright, A.P. 1974. By the Waters of Letaba: A History of the Transvaal Lowveld. Cape Town: Purnell.

9. Childs, S.T. 1989. "Clays to artifacts: resource selection in African Early Iron Age iron making technologies." In Pottery Technology, Ideas and Approaches, edited by G. Bronitsky, 139-164. Boulder: Westview Press.

10. Chirikure, S. 2007. "Metals in society: iron production and its position in Iron Age communities of southern Africa." Journal of Social Archaeology 7: 72-100. doi: 10.1177/1469605307073164 [CrossRef], [Web of Science ${ }^{\circledR}$ ]

11. Chirikure, S. 2010. Indigenous Mining and Metallurgy in Africa. Cambridge: Cambridge University Press.

12. Chirikure, S. 2014. "Land and sea links: 1500 years of connections between southern Africa and the Indian Ocean rim regions, AD 700 to 1700." African Archaeological Review 31: 705-724. doi: 10.1007/s10437-014-9171-6 [CrossRef], [Web of Science ${ }^{\circledR}$ ]

13. Chirikure, S. 2015. Metals in Past Societies: A Global Perspective on Indigenous African Metallurgy. New York: Springer. 


\section{[CrossRef]}

14. Chirikure, S., Hall, S. and Rehren, T. 2015. "When ceramic sociology meets material science: sociological and technological aspects of crucible and pottery from Mapungubwe, southern Africa." Journal of Anthropological Archaeology 40: 23-32. doi: 10.1016/j.jaa.2015.05.004 [CrossRef], [Web of Science ${ }^{\circledR}$ ]

15. Chirikure, S. and Rehren, T. 2004. "Ores, furnaces, slags and prehistoric societies: aspects of iron working in the Nyanga agricultural complex, AD 1300-1900." African Archaeological Review 21: 135-152. doi: 10.1023/B:AARR.0000045827.70774.56 [CrossRef]

16. Chirikure, S. and Rehren, T. 2006. "Iron smelting in precolonial Zimbabwe: evidence for diachronic change from Swart Village and Baranda, northern Zimbabwe." Journal of African Archaeology 4: 37-53. doi: 10.3213/1612-1651-10062 [CrossRef]

17. Cline, W. 1937. Mining and Metallurgy in Negro Africa. Menasha: George Banta Publishing Company.

18. Cooke, S.R. and Aschenbrenner, S. 1975. "The occurrence of metallic iron in ancient copper." Journal of Field Archaeology 2: 251266. [Taylor \& Francis Online]

19. Craddock, P.T. 1985. "Medieval copper alloy production and West African bronze analyses- Part I." Archaeometry 27: 17-41. doi: 10.1111/j.1475-4754.1985.tb00344.x [CrossRef], [Web of Science ${ }^{\circledR}$ ]

20. Craddock, P.T. 1995. Early Metal Mining and Production. Edinburgh: Edinburgh University Press.

21. Craddock, P.T. 2009. "Evidences for the earliest smelting processes in western Europe." In Archaeometallurgy in Europe: 2nd International Conference, Associazione Italiana di Metallurgia, Aquileia, Italy, 3-11. Milan: Associazione Italiana di Metallurgia.

22. Craddock, P.T., Ambers, J., Hook, D.R., Farquhar, R.M., Chikwendu, V.E. and Umeji, D.C. 1997. "Metal sources and the bronzes from Igbo-Ukwu, Nigeria." Journal of Field Archaeology 24: 405-429. [Taylor \& Francis Online], [Web of Science ${ }^{\circledR}$ ]

23. Craddock, P.T. and Craddock, B.R. 1996. "The beginnings of metallurgy in south-west Britain: hypothesis and evidence." Bulletin of the Peak District Mines Historical Society 13: 52-63.

24. Craddock, P.T. and Meeks, N.D. 1987. "Iron in ancient copper." Archaeometry 2: 187-204. doi: 10.1111/j.14754754.1987.tb00411.x [CrossRef], [Web of Science ${ }^{\circledR}$ ]

25. Craddock, P.T. and Picton, J. 1986. "Medieval copper alloy production and West African Bronze analyses- Part II." Archaeometry 28: 3-32. doi: 10.1111/j.1475-4754.1986.tb00371.x [CrossRef], [Web of Science ${ }^{\circledR}$ ]

26. David, D., Heimann, R., Killick, D. and Wayman, M. 1989. 
"Between bloomery and blast furnace: Mafa iron-smelting technology in north Cameroon." African Archaeological Review 7: 183-208. doi: 10.1007/BF01116843 [CrossRef]

27. Davison, C.C. 1973. "Chemical resemblance of garden roller and M1 glass beads." African Studies 32: 247-257. doi: 10.1080/00020187308707414 [Taylor \& Francis Online], [Web of Science ${ }^{\circledR}$ ]

28. Ericksson, S.C. 1984. "Age of carbonatite and phoscorite magmatism of the Phalaborwa Complex (South Africa)." Isotope Geosciences 2: 291-299.

29. Evers, T.M. and van der Berg, R.P. 1974. "Ancient mining in southern Africa, with reference to a copper mine in the Harmony Block, north-eastern Transvaal." Journal of the South African Institute of Mining and Metallurgy 74: 217-226. [Web of Science ${ }^{\circledR}$ ]

30. Evers, T.M. and van der Merwe, N.J. 1987. "Iron Age ceramics from Phalaborwa north eastern Transvaal Lowveld, South Africa." South African Archaeological Bulletin 42: 87-106. doi: 10.2307/3888735 [CrossRef]

31. Fagan, B.M. 1969. "Early trade and raw materials in South Central Africa." Journal of African History 10: 1-13. doi: 10.1017/S0021853700009245 [CrossRef], [Web of Science ${ }^{\circledR}$ ]

32. Freestone, I.C. 1989. "Refractory materials and their procurement." In Old World Archeometallurgy, edited by A. Hauptman, E. Pernicka and G.A. Wagner, 155-161. Bochum: Selbestverlag des Deutschen Bergbau-Museums.

33. Freestone, I.C. and Tite, M.S. 1986. "Refractories in the ancient and preindustrial world." In High Technology Ceramics: Past, Present and Future. The Nature of Innovation and Change in Ceramic Technology, edited by W.D. Kingery, 35-63. Westerville: The American Ceramic Society.

34. Friede, H.M. 1975. "Notes on the composition of preEuropean copper and copper alloy artefacts from the Transvaal." Journal of the South African Institute of Mining and Metallurgy 75: 185-191. [Web of Science ${ }^{\circledR}$ ]

35. Friede, H.M. 1980. "Iron Age mining in the Transvaal." Journal of the South African Institute of Mining and Metallurgy 80: 156-165. [Web of Science ${ }^{\circledR}$ ]

36. Friede, H.M., Hejja, A.A. and Koursaris, A. 1982. "Archaeometallurgical studies of iron smelting slags from prehistoric sites in southern Africa." Journal of the South African Institute of Mining and Metallurgy 83: 38-48.

37. Friede, H.M. and Steel, R.H. 1975. "Notes on Iron Age copper smelting technology in the Transvaal." Journal of the South African 
Institute of Mining and Metallurgy 76: 221-231. [Web of Science ${ }^{\circledR}$ ]

38. Grant, M. and Huffman, T.N. 2007. "The extractive metallurgy of copper at Iron Age Madikwe." South African Journal of Science 103: 403-408. [Web of Science ${ }^{\circledR}$ ]

39. Greenfield, H.J. and Miller, D.E. 2004. "Spatial patterning of Early Iron Age metal production at Ndondondwane, South Africa: the question of cultural continuity between the Early and Late Iron Ages." Journal of Archaeological Science 31: 1511-1532. doi: 10.1016/j.jas.2004.03.014 [CrossRef], [Web of Science ${ }^{\circledR}$ ]

40. Groves, D.I. and Vielreicher, M.N. 2001. "The Palaborwa (Palabora) carbonatite-hosted magnetite-copper-sulphide deposit, South Africa: an end member of iron-oxide copper-gold-rare earth element deposit group?" Mineral Deposita 36: 189-194. doi: 10.1007/s001260050298 [CrossRef], [Web of Science ${ }^{\circledR}$ ]

41. Haaland, G., Haaland, R. and Dea, D. 2004. "Furnace and pot: why the iron smelter is a big pot maker, a case study from southwestern Ethiopia." Azania 39: 146-165. doi: 10.1080/00672700409480394 [Taylor \& Francis Online]

42. Haaland, R. 2004. "Iron smelting - a vanishing tradition: ethnographic study of this craft in south-west Ethiopia." Journal of African Archaeology 2: 65-79.

43. Hall, S.L., Miller, D.E., Anderson, M. and Boeyens, J. 2006. "An exploratory study of copper and iron production at Marathodi, an early 19th century Tswana Town, Rustenburg District, South Africa." Journal of African Archaeology 4: 3-35. doi: 10.3213/1612-1651-10061 [CrossRef]

44. Hanisch, E.O. 1974. "Copper working in the Messina district." Journal of South African Institute of Mining and Metallurgy 74: 250253. [Web of Science ${ }^{\circledR}$ ]

45. Herbert, E.W. 1996. "Metals and power at Great Zimbabwe." In Aspects of African Archaeology, edited by G. Pwiti, and R.C. Soper, 641-647. Harare: University of Zimbabwe Publications.

46. Hogg, A.G., Hua, Q., Blackwell, P.G., Niu, M., Buck, C.E., Guilderson, T.P., Heaton, T.J., Palmer, J.G., Reimer, P.J., Reimer, R.W., Turney, C.S.M. and Zimmerman, S.R.H. 2013. "SHCal13 Southern Hemisphere calibration, 0-50,000 years cal BP." Radiocarbon 55: 18891903. doi: 10.2458/azu_js_rc.55.16783 [CrossRef], [Web of Science ${ }^{\circledR}$ ]

47. Huffman, T.N. 1986a. "Archaeological evidence and conventional explanations of southern Bantu settlement patterns." Journal of the International African Institute 56: 280-298. doi: 10.2307/1160685 [CrossRef], [Web of Science ${ }^{\circledR}$ ]

48. Huffman, T.N. 1986b. "Iron Age settlement patterns and the origins of class distinction in southern Africa." Advances in World 
Archaeology 5: 291-338.

49. Huffman, T.N. 2005. Mapungubwe: Ancient Civilization on the Limpopo. Johannesburg: Witwatersrand University Press.

50. Huffman, T.N. 2007. Handbook to the Iron Age: The Archaeology of Pre-colonial Farming Societies in Southern Africa. Scottsville: University of KwaZulu-Natal Press.

51. Humphris, J., Martinón-Torres, M., Rehren, T. and Reid, D.A.M. 2009. "Variability in single smelting episodes - a pilot study using iron slag from Uganda." Journal of Archaeological Science 36: 359-369. doi: 10.1016/j.jas.2008.09.020 [CrossRef], [Web of Science ${ }^{\circledR}$ ]

52. Ige, A. and Rehren, T. 2003. "Black sand and iron stone: iron smelting in Modakeke, Ife, south western Nigeria." Institute of Archaeo-Metallurgical Studies 23: 15-20.

53. Iles, L. and Martinón-Torres, M. 2009. "Pastoralist iron production on the Laikipia Plateau, Kenya: wider implications for archaeometallurgical studies." Journal of Archaeological Science 36: 2314-2326. doi: 10.1016/j.jas.2009.06.023 [CrossRef], [Web of Science $\left.{ }^{\circledR}\right]$

54. Killick, D.J. 1977. "An attempt to trace the movement of the ores in the Transvaal Lowveld by XRF analysis of slags." BA Honours diss., University of Cape Town.

55. Killick, D.J. 2009a. "Agency, dependency and long distance trade: East Africa and the Islamic world 700-1500CE." In Polities and Power: Archaeological Perspectives on the Landscapes of Early States, edited by S. Falconer and C. Redman, 179-207. Tucson: University of Arizona Press.

56. Killick, D. 2009b. "Cairo to Cape: the spread of metallurgy through eastern and southern Africa." Journal of World Prehistory 22: 399-414. doi: 10.1007/s10963-009-9025-3 [CrossRef], [Web of Science $\left.{ }^{\circledR}\right]$

57. Killick, D.J. and Miller, D.E. 2014. "Smelting of magnetite and magnetite-ilmenite iron ores in the northern Lowveld, South Africa, ca. 1000 CE to ca. 1880 CE." Journal of Archaeological Science 43: 239255. doi: 10.1016/j.jas.2013.12.016 [CrossRef], [Web of Science ${ }^{\circledR}$ ]

58. Klapwijk, M. 1986. "Some notes on the tuyères from smelting sites in the north-eastern Transvaal, South Africa." South African Archaeological Bulletin 41: 17-21. doi: 10.2307/3887713 [CrossRef]

59. Kowalski, M., Spences, P.J. and Neuschutz, D. 1995. "Phase diagrams". In Slag Atlas. Second Edition, edited by V.D. Eisenhuttenleute, 21-214. Dussteldoff: Verlag Stahleisen GmbH.

60. Küsel, U.S. 1974. "Extractive metallurgy in Iron Age South Africa." Journal of the South African Institute of Mining and Metallurgy 
74: 246-249. [Web of Science ${ }^{\circledR}$ ]

61. Maddin, R. 1988. "Technical studies-early use of metals." In Materials Issues in Art and Archaeology: Materials research Society Symposium Proceedings, edited by E. V. Saryer, P. Vandiver, J. Druzik and C. Steveson, Vol. 123: 171-181. Pittsburgh: Materials Research Society. [CrossRef]

62. Maggs, T.M.O'C. and Miller, D. 1995. "Sandstone crucibles from Mhlopeni, KwaZulu-Natal: evidence of precolonial brassworking." Natal Museum Journal of Humanities 7: 1-16.

63. Mamadi, M. 1940. "The copper miners of Musina." In The Copper Miners of Musina and the Early History of the Zoutpansberg, edited by N. van Warmelo, 81-87. Pretoria: South African Ethnological Publications.

64. Martinón-Torres, M. and Rehren, T. 2002. "Agricola and Zwickau: theory and practice of Renaissance brass production in SE Germany." Historical Metallurgy 36: 95-111.

65. Martinón-Torres, M. and Rehren, T. 2009. "Post-medieval crucible production and distribution: a study of materials and materialities." Archaeometry 51: 49-74. doi: 10.1111/j.14754754.2007.00380.x [CrossRef], [Web of Science ${ }^{\circledR}$ ]

66. Mason, R.J. 1965. "The origin of South African society." South African Journal of Science 61: 255-267.

67. Mason, R.J. 1982. "Prehistoric mining in South Africa and Iron Age copper mines in the Dwarsberg, Transvaal." Journal of the South African Institute of Mining and Metallurgy 82: 134-144. [Web of Science ${ }^{\circledR}$ ]

68. Mason, R.J. 1986. Origins of Black People of Johannesburg and the Southern Western Central Transvaal AD 350-1880. Johannesburg: Archaeological Research Unit, University of the Witwatersrand.

69. Mason, R.J., Brown, A.J., Fatti, L.P. and Beardall, G. 1983. "Cluster and correspondance analysis of Iron Age faunal assemblages, circa AD 350-510 and AD 1550-1850 from southern, western and eastern Transvaal." South African Journal of Science 79: 182-203.

70. Merkel, J.F. 1990. "Experimental reconstruction of Bronze Age copper smelting based on archaeological evidence from Timna." In The Ancient Metallurgy of Copper: Archaeology-Experiment-Theory, edited by B. Rothernberg, 78-122. London: Institute for ArchaeoMetallurgical Studies.

71. Miller, D.E. 2001a. "Indigenous iron production in southern Africa: archaeological observations and interpretation." Meditarch 14: 229-234.

72. Miller, D.E. 2001b. "Metal assemblages from Greesfwald 
area K2, Mapungubwe Hill and Mapungubwe South Terrace." South African Archaeological Bulletin 56: 83-103. doi: 10.2307/3889031 [CrossRef], [Web of Science ${ }^{\circledR}$ ]

73. Miller, D.E. 2002. "Smelter and smith: Iron Age metal fabrication technology in southern Africa." Journal of Archaeological Science 29: 1083-1131. doi: 10.1006/jasc.2001.0758 [CrossRef], [Web of Science $\left.{ }^{\circledR}\right]$

74. Miller, D.E. 2003. "Indigenous copper mining and smelting in pre-colonial southern Africa." In Mining and Metal Production Through the Ages, edited by P.T. Craddock and J. Lang, 101-110. London: The British Museum Press.

75. Miller, D.E. 2010. "Indigenous metal melting and casting in southern Africa." South African Archaeological Bulletin 65: 45-57. [Web of Science ${ }^{\circledR}$ ]

76. Miller, D.E., Boeyens, J. and Küsel, M. 1995. "Metallurgical analyses of slags, ores, and metal artefacts from archaeological sites in the North-West Province and Northern Transvaal." South African Archaeological Bulletin 50: 39-54. doi: 10.2307/3889273 [CrossRef]

77. Miller, D.E., Desai, N. and Lee-Thorp, J.A. 2000. "Indigenous gold mining in southern Africa: a review." South African Archaeological Society Goodwin Series 8: 91-99. [CrossRef]

78. Miller, D.E. and Killick, D. 2004. "Slag identification at southern African archaeological sites." Journal of African Archaeology 2: 23-47. doi: 10.3213/1612-1651-10017 [CrossRef]

79. Miller, D.E., Killick, D. and van der Merwe, N.J. 2001. "Metal working in the Northern Lowveld, South Africa, A.D. 1000-1890." Journal of Field Archaeology 28: 401-417. doi: 10.1179/jfa.2001.28.34.401 [Taylor \& Francis Online], [Web of Science ${ }^{\circledR}$ ]

80. Miller, D.E., Mulaudzi, M. and Killick, D. 2002. "An historical account of iron smelting in the Lowveld, South Africa." Historical Metallurgy 36: 112-121.

81. Miller, D.E. and Sandelowsky, B. 1999. "Smelting without ceramics: the Drierivier copper smelting site near Rehoboth, Namibia." South African Archaeological Bulletin 54: 28-37. doi: 10.2307/3889137 [CrossRef], [Web of Science ${ }^{\circledR}$ ]

82. Miller, D.E. and van der Merwe, N.J. 1994a. "Early metal working in sub-Saharan Africa: a review of recent research." Journal of African History 35: 1-36. doi: 10.1017/S0021853700025949 [CrossRef], [Web of Science ${ }^{\circledR}$ ], [CSA]

83. Miller, D.E. and van der Merwe, N.J. 1994b. "Early Iron Age metal working at the Tsodilo Hills, northwestern Botswana." Journal of Archaeological Science 21: 101-115. doi: 10.1006/jasc.1994.1011 [CrossRef], [Web of Science ${ }^{\circledR}$ ] 
84. Mitchell, P.J. 2002. The Archaeology of Southern Africa. Cambridge: Cambridge University Press.

85. Mitchell, P.J. 2005. African Connections: Archaeological Perspectives on Africa and the Wider World. Walnut Creek: AltaMira Press.

86. More, C.E. 1974. "Some observations on 'ancient' mining at Phalaborwa." Journal of the South African Institute of Mining and Metallurgy 74: 227-232. [Web of Science ${ }^{\circledR}$ ]

87. Morton, G.R. and Wingrove, J. 1969. "Constitution of bloomery slags. Part I: Roman." Journal of the Iron and Steel Institute 207: 1556-1564. [Web of Science ${ }^{\circledR}$ ]

88. Morton, G.R. and Wingrove, J. 1972. "Constitution of bloomery slags. Part II: Medieval." Journal of the Iron and Steel Institute 210: 478-488. [Web of Science ${ }^{\circledR}$ ]

89. Muller, R., Rehren, T. and Rovira, S. 2004. "Almizaraque and the early copper metallurgy of southeast Spain: new data." Madridier Mutteilungen 45: 33-56.

90. Orton, C. 2000. Sampling in Archaeology. Cambridge: Cambridge University Press. [CrossRef]

91. Palabora Mining Company Limited Mine Geological and Mineralogical Staff. 1976. "The geology and economic deposits of copper, iron and vermiculite in the Palabora Igneous Complex: a brief review." Economic Geology 71: 177-192. doi: 10.2113/gsecongeo.71.1.177 [CrossRef], [Web of Science ${ }^{\circledR}$ ]

92. Pernicka, E. 2004. "Archaeometallurgy: examples of the application of scientific methods to provenance of archaeological metal objects." In Physics Methods in Archaeometry, edited by M. Martini, M. Milazzo and M. Piacentini, 309-329. Amsterdam: IOS Press.

93. Pikirayi, I. 2001. The Zimbabwe Culture: Origins and Decline of Southern Zambezian States. New York: AltaMira Press.

94. Pistorius, J.C. 1989. "Die metaalbewerkers van Phalaborwa." PhD diss., University of Pretoria. Pretoria.

95. Plug, I. and Pistorius, J.C. 1999. "Animal remains from the industrial Iron Age communities in Phalaborwa, South Africa." African Archaeological Review 16: 155-184. doi: 10.1023/A:1021676616468 [CrossRef]

96. Pryce, T.O., Pigott, V.C., Martinón-Torres, M. and Rehren, T. 2010. "Prehistoric copper production and technological reproduction in the Khao Wong Prachan Valley." Archaeological and Anthropological Sciences 2: 237-264. doi: 10.1007/s12520-010-0043-y [CrossRef], [Web of Science ${ }^{\circledR}$ ]

97. Pwiti, G. 1991. "Trade and economies in southern Africa: the archaeological evidence." Zambezia 18: 119-129. 
98. Redman, C.L. 1987. "Surface collection, sampling and research design: a retrospective." American Antiquity 52: 249-265. doi: 10.2307/281779 [CrossRef], [Web of Science ${ }^{\circledR}$ ]

99. Rehren, T. 2003. "Crucibles as reaction vessels in ancient metallurgy." In Mining and Metal Production through the Ages, edited by P.T. Craddock, and J. Lang, 207-215. London: British Museum Press.

100. Rehren, T. 1999. "Small size, large scale Roman brass production in Germania Inferior." Journal of Archaeological Science 26: 1083-1087. doi: 10.1006/jasc.1999.0402 [CrossRef], [Web of Science ${ }^{\circledR}$ ]

101. Reid, D.A.M. and MacLean, R. 1995. "Symbolism and the social contexts of iron production in Karagwe." World Archaeology 27: 144-161. doi: 10.1080/00438243.1995.9980298 [Taylor \& Francis Online], [Web of Science ${ }^{\circledR}$ ], [CSA]

102. Roux, E.H., de Jager, D.H., du Plooy, J.H., Nicotra, A., van der Linde, G.J. and de Waal, P. 1989. "Phosphates in South Africa." Journal of the South African Institute of Mining and Metallurgy 89: 129-139. [Web of Science ${ }^{\circledR}$ ]

103. Rowlands, M.J. 1971. "The archaeological interpretation of prehistoric metalworking." World Archaeology 3: 210-224. doi: 10.1080/00438243.1969.9979502 [Taylor \& Francis Online], [Web of Science ${ }^{\circledR}$ ]

104. Russell, H.D., Hiemstra, S.A. and Groeneveld, D. 1954. "The mineralogy and petrology of the carbonatite at Loolekop, Eastern Transvaal." Transactions of the Geological Society of South Africa 57: 197-208.

105. Schiffer, M.B., Sullivan, A.P. and Klinger, T.C. 1978. "The design of archaeological surveys." World Archaeology 10: 1-28. doi: 10.1080/00438243.1978.9979712 [Taylor \& Francis Online], [Web of Science $\left.{ }^{\circledR}\right]$

106. Schryver, J. 1970. "A preliminary description and typology of pottery of Kgopolwe Hill of Palabora area, Northern Transvaal." MA diss., State University of New York at Binghamton.

107. Schwellnus, C.M. 1937. "Short notes on the Palabora smelting ovens." South African Journal of Science 33: 904-912.

108. Scott, D.A. 1991. Metallography and Microstructure of Ancient Metals and Historic Metals. Los Angeles: The J Paul Getty Conservation Institute in association with Archetype Books.

109. Shennan, S. 1998. "Producing copper in the eastern Alps during the second millennium BC." In Social Approaches to an Industrial Past: The Archaeology and Anthropology of Mining, edited by A.B. Knapp; V.C. Pigott and E.W. Herbert, 191-204. London: Routledge.

110. Stanley, G.H. 1929a. "Primitive metallurgy in South Africa: some products and their significance." South African Journal of Science 
26: 732-748.

111. Stanley, G.H. 1929b. "The composition of some prehistoric South African bronzes with notes on the methods of analysis." South African Journal of Science 26: 44-49.

112. Stayt, H. 1931. The BaVenda. London: Oxford University Press.

113. Stevenson-Hamilton, J. 1974. South Africa Eden: From Sabi Game Reserve to Kruger National Park. London: William Collins Sons and Co Ltd.

114. Stuiver, M. and van der Merwe, N.J. 1968. "Radiocarbon chronology of the Iron Age in sub-Saharan Africa." Current Anthropology 9: 54-58. doi: 10.1086/200878 [CrossRef], [Web of Science $\left.{ }^{\circledR}\right]$

115. Summers, R. 1969. Ancient Mining in Rhodesia and Adjacent Areas. Salisbury: Trustees of the National Museums of Rhodesia.

116. Thondhlana, T.P. 2012. "Metalworkers and smelting precincts: technological reconstructions of second millennium copper production around Phalaborwa, northern Lowveld of South Africa." PhD diss., University College London.

117. Thondhlana, T.P. and Martinón-Torres, M. 2009. "Small size, high value: composition and manufacture of second millennium AD copper-based beads from northern Zimbabwe." Journal of African Archaeology 7: 79-97. doi: 10.3213/1612-1651-10119 [CrossRef], [Web of Science $\left.{ }^{\circledR}\right]$

118. Thorne, R.M. 1974. "Archaeological survey in South Africa: conceptual, methodological and practical problems: the Phalaborwa Complex - a case study." PhD diss., University of Missouri, Columbia.

119. Thornton, C.P., Golden, J.M., Killick, D.J., Pigott, V.C., Rehren, T. and Roberts, B.W. 2010. "A Chalcolithic error: rebuttal to Amzallag 2009." American Journal of Archaeology 114: 305-315. doi: 10.3764/aja.114.2.305 [CrossRef], [Web of Science ${ }^{\circledR}$ ]

120. Thorton, C. P., Rehren, T. and Pigott, V.C. 2009. "The production of speiss (iron arsenide) during the Early Bronze Age in Iran." Journal of Archaeological Science 36: 308-316. doi: 10.1016/j.jas.2008.09.017 [CrossRef], [Web of Science ${ }^{\circledR}$ ]

121. Tylecote, R.F. and Merkel, J.F. 1985. "Experimental smelting techniques: achievements and future." In Furnaces and Smelting Technology in Antiquity, edited by P.T. Craddock, and M.J. Hughes, 320. London: British Museum.

122. Tylecote, R.F., Ghaznavi, H.A. and Boydell, P.J. 1977. "Partitioning of trace elements between ores, fluxes, slags and metal during the smelting of copper." Journal of Archaeological Sciences 4: 
305-333. doi: 10.1016/0305-4403(77)90027-9 [CrossRef], [Web of Science $\left.{ }^{\circledR}\right]$

123. van der Merwe, N.J. 1978. "Field methodology and Iron Age metallurgy at Buhwa, Rhodesia." Occasional Papers of the National Museums and Monuments of Rhodesia 4: 101-105.

124. van der Merwe, N.J. and Killick, D. 1979. "Square: an iron smelting site near Phalaborwa." South African Archaeological Society Goodwin Series 3: 86-193.

125. van der Merwe, N.J. and Scully, R.T. 1971. "The Phalaborwa story: archaeological and ethnographic investigation of a South African Iron Age group." World Archaeology 3: 178-196. doi: 10.1080/00438243.1969.9979500 [Taylor \& Francis Online], [Web of Science $\left.{ }^{\circledR}\right]$

126. van Waarden, C. 2014. "Prehistoric copper mining in Botswana." In Encyclopaedia of History of Science, Technology and Medicine in Non-Western Cultures, edited by H. Selin, 1-13. New York: Springer Science. [CrossRef]

127. Viljoen, M.J., and Reimold, W.U. 1999. An Introduction to South Africa's Geological and Mining Heritage. Randburg: Mintek.

128. Wood, M. 2011. Interconnections: Glass Beads and Trade in Southern and Eastern Africa and the Indian Ocean - 7th to 16th centuries AD. Uppsala: Uppsala University Department of Archaeology and Ancient History. 


\section{Images and Tables}

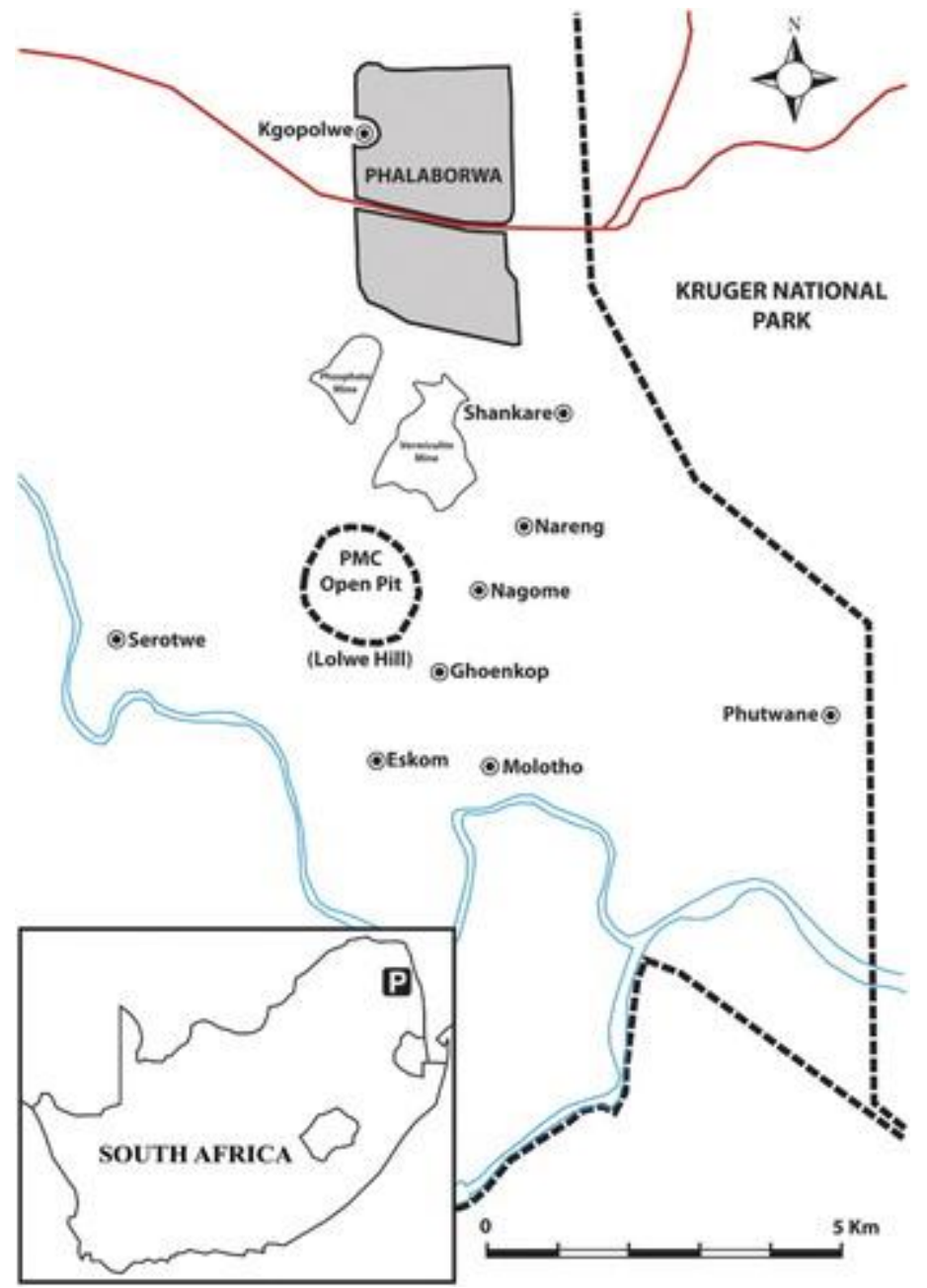

Figure 1. Map of Phalaborwa showing the location of Shankare Hill and other related sites mentioned in this paper (Insert map of South Africa). 


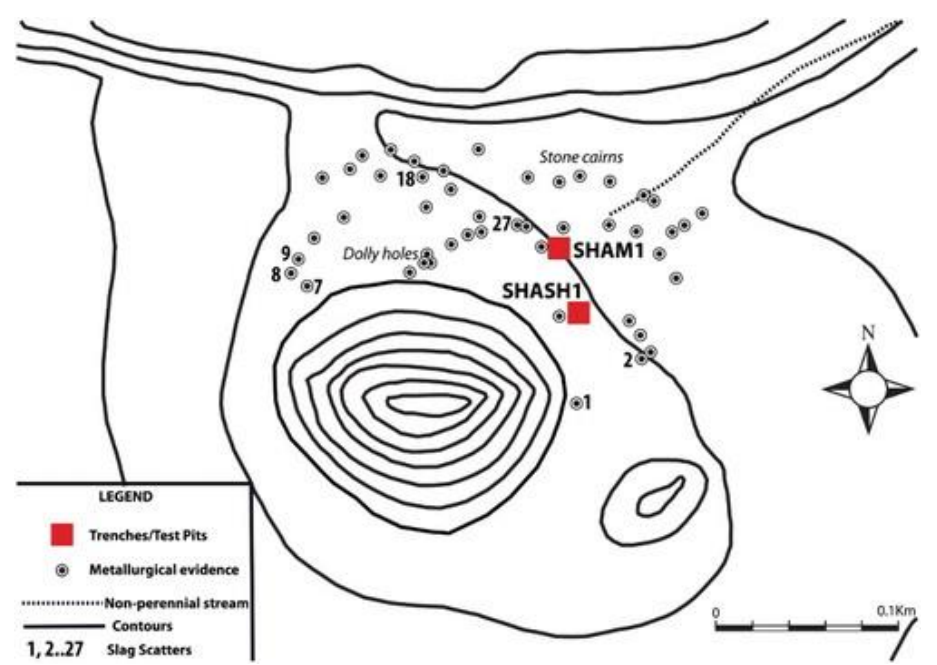

Figure 2. Shankare Hill: sketch plan of the activity areas and location of our excavated test pits. The activity areas and test pits are not drawn to scale (Map compiled by GEM-Science from GPS coordinates). 


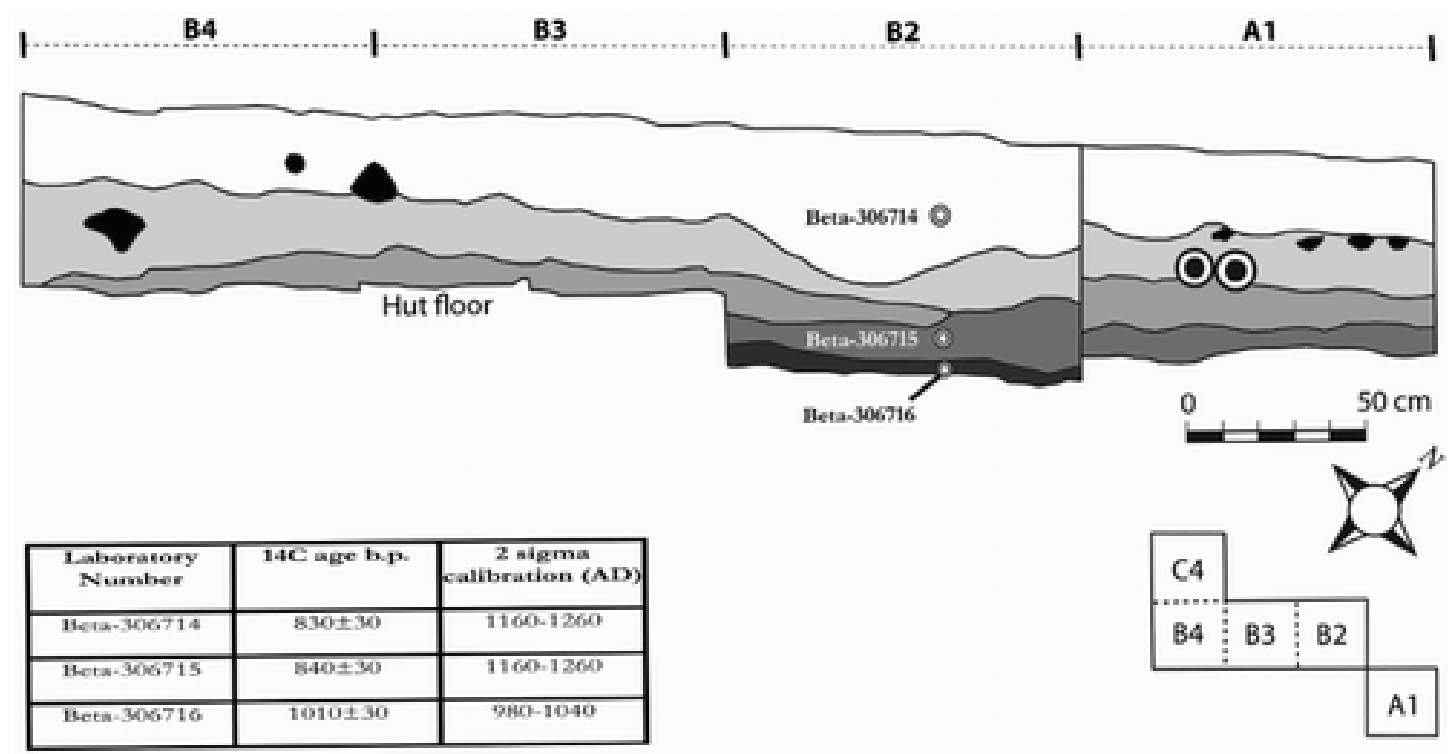

Figure 3. Shankare Hill: section illustrations from trench SHAM1 showing the stratigraphic units. 


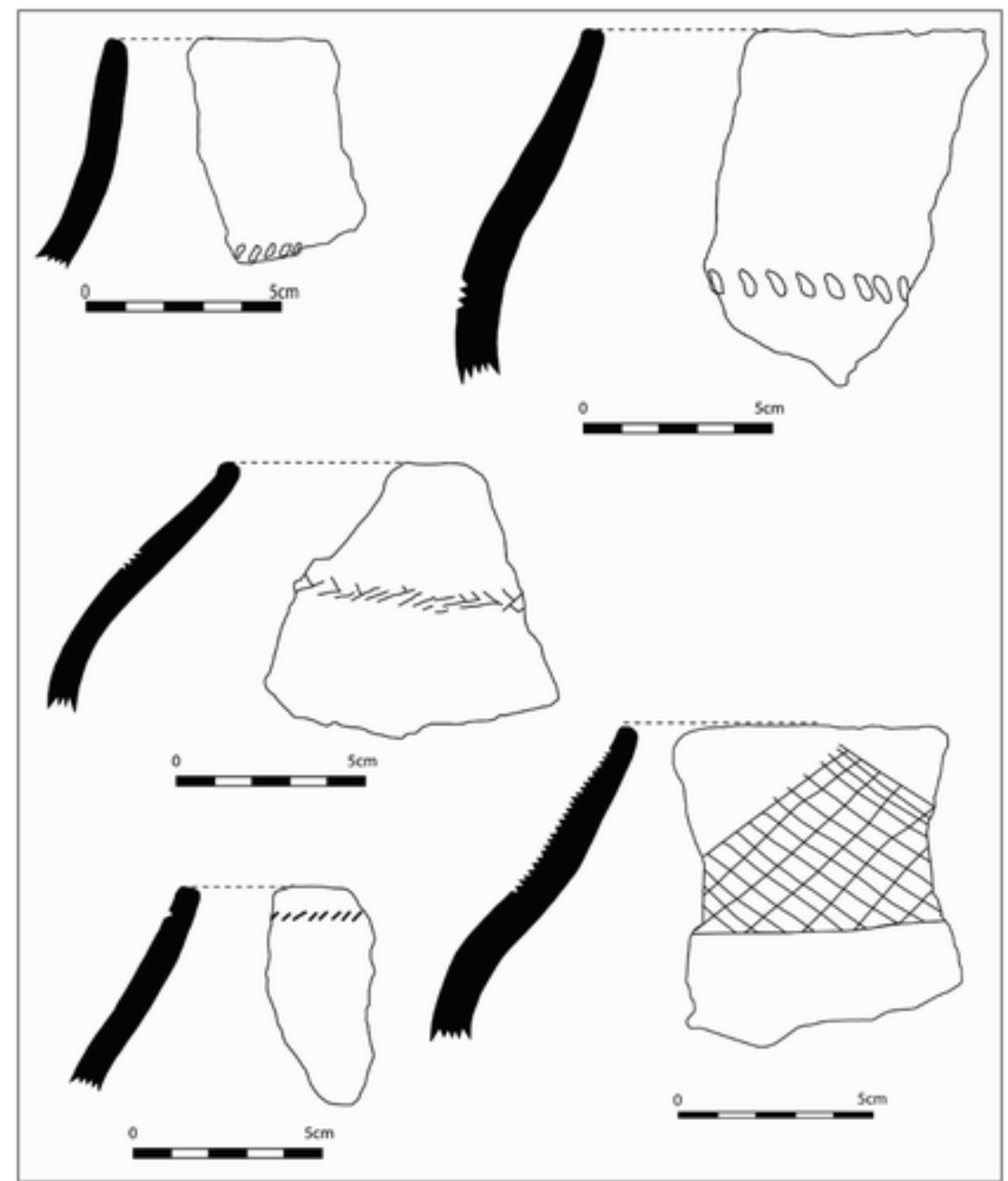

Figure 4. Shankare Hill: typical Kgopolwe pottery with necked jars from midden SHAM1 presumably dating to the tenth to thirteenth centuries $A D$ (drawings by Foreman Bandama). 

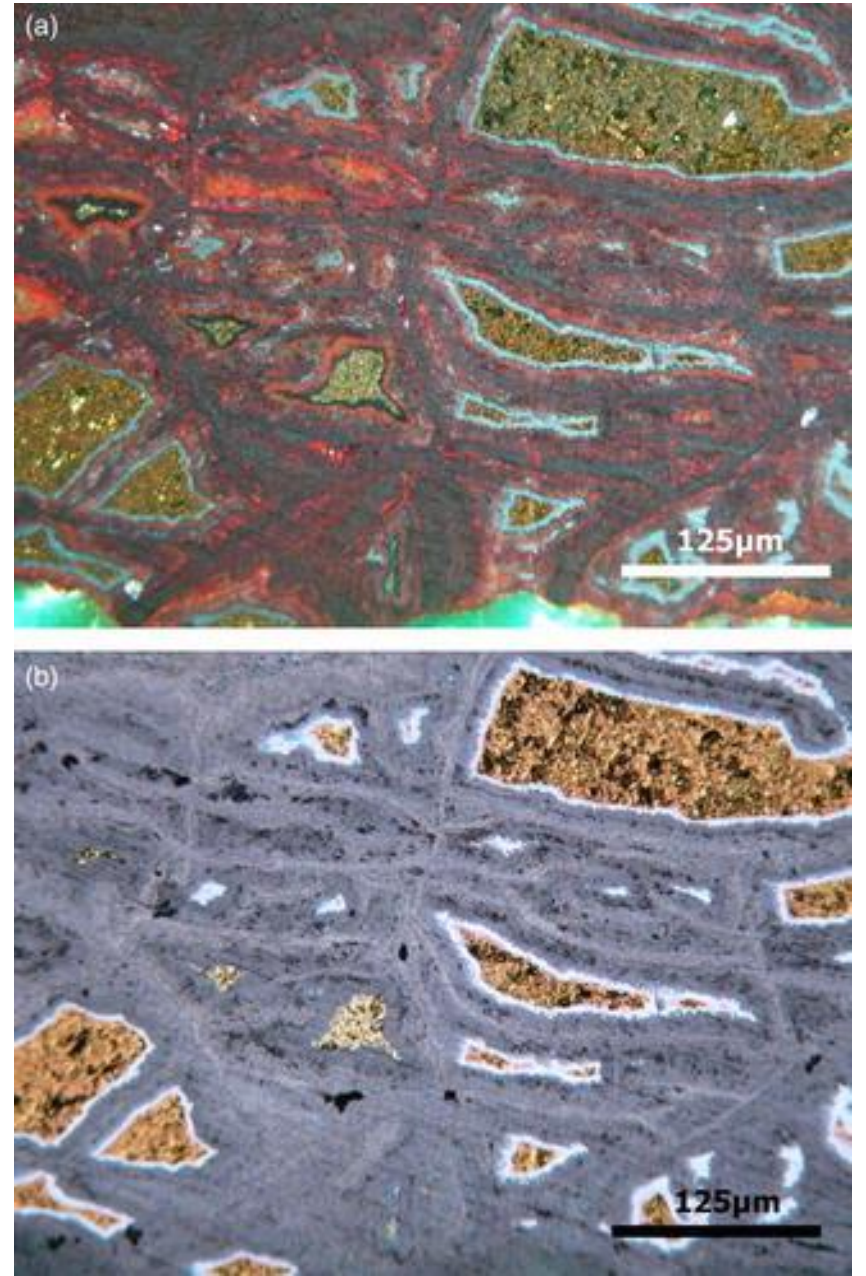

Figure 5. a) Shankare Hill: photomicrographs of the presumed ore sample SHA13NEL showing brassy chalcopyrite surrounded by thin light blue rims of chalcocite enclosed together in a copper and iron bearing red matrix. The green matrix is malachite. Photomicrograph under cross-polarised light (200x magnification); b) photomicrographs of the presumed ore sample SHA13NEL showing brassy chalcopyrite surrounded by thin light blue rims of chalcocite enclosed together in a copper and iron bearing red matrix (taken under plane-polarised light (200x magnification)). 


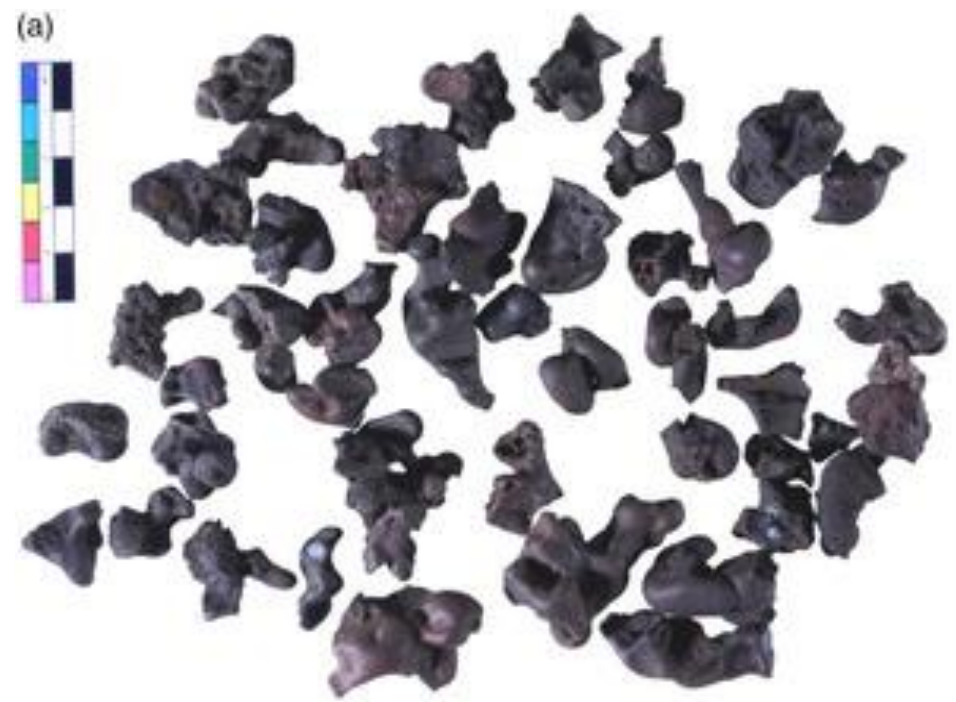

(b)

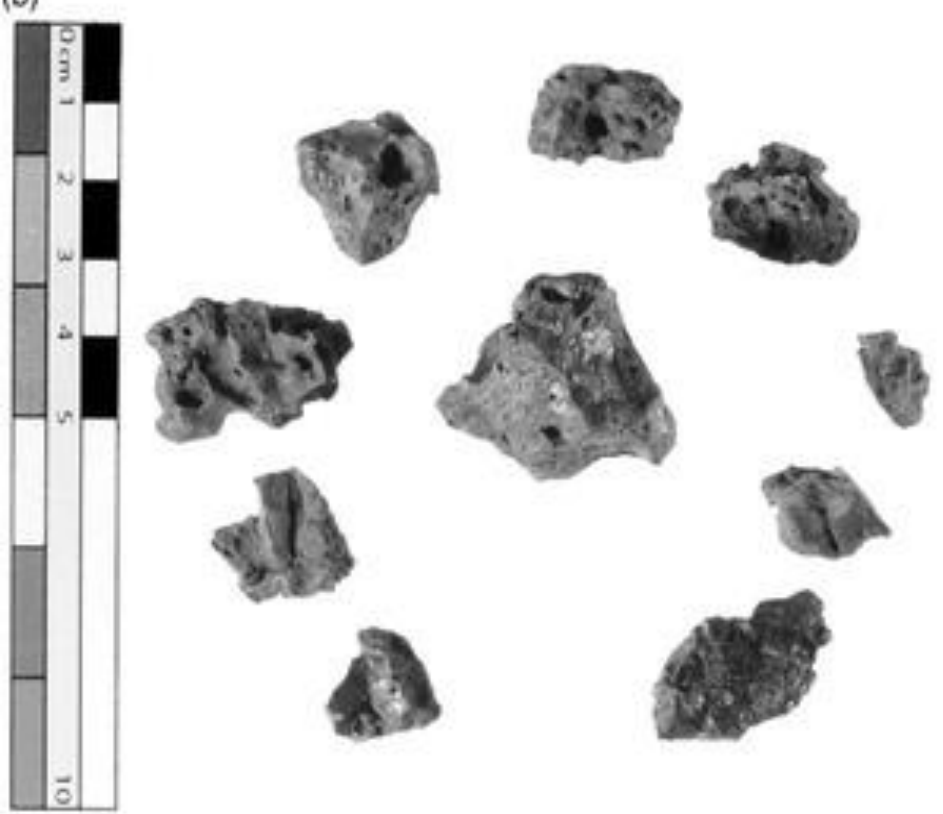

Figure 6. a) Furnace slags recovered from Shankare Hill that solidified from a fully molten state; b) Shankare Hill: crushed slags with visible residual magnetite ore and copper prills. 

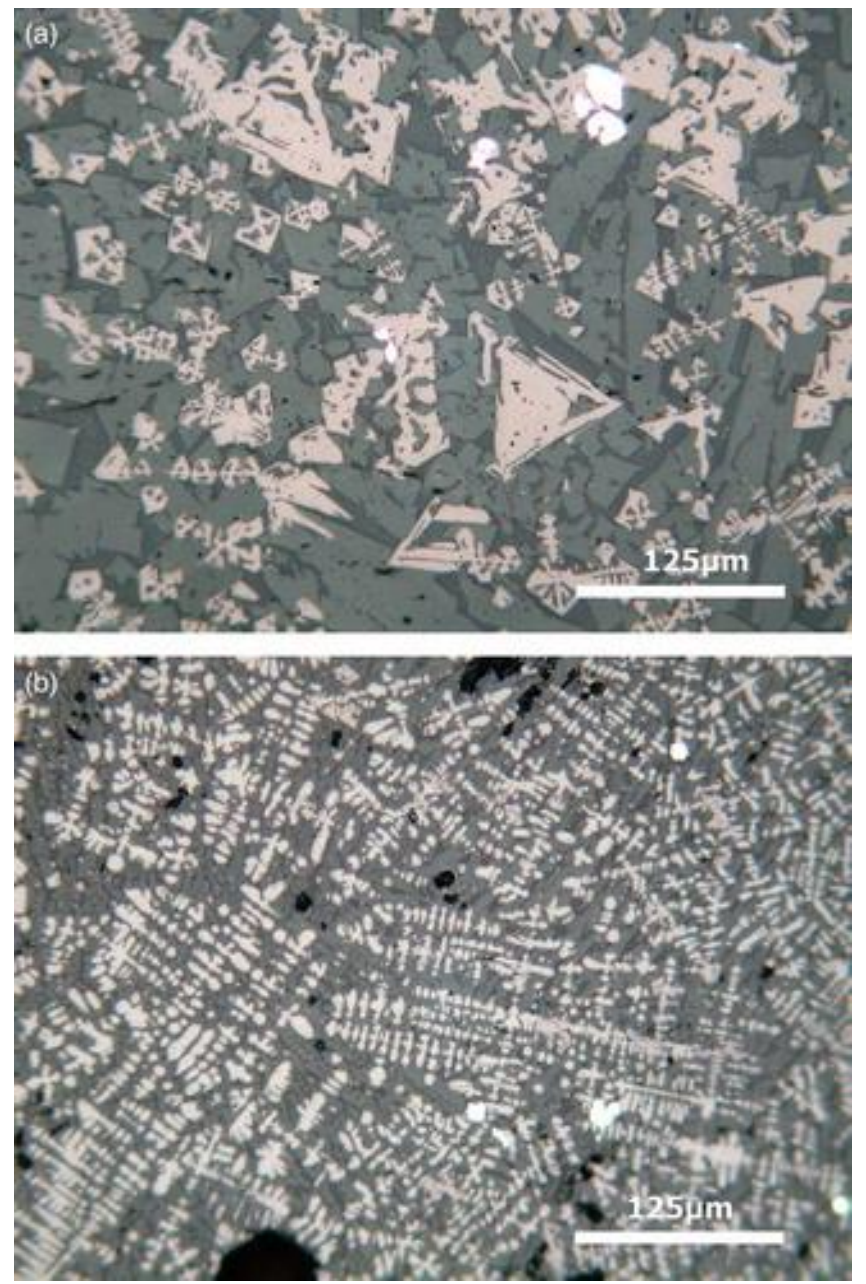

Figure 7. Shankare Hill a) BSE image of sample SHA2NEL showing the dominant blocky olivines and ulvospinels. (GROUP 1 iron slags); b) BSE image of sample SHA8NEL showing the dominant wüstite dendrites and olivines. (GROUP 2 iron slags). 


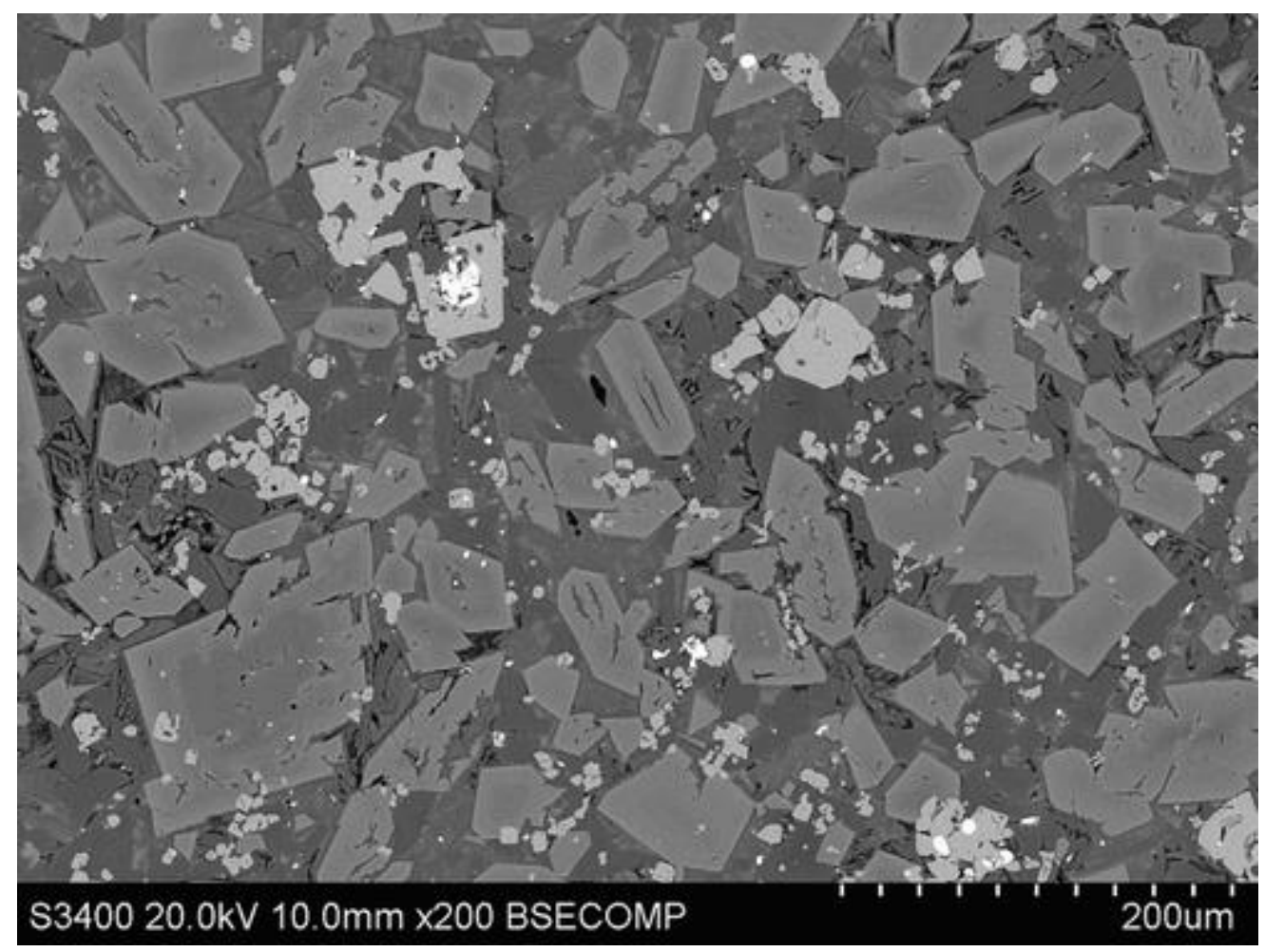

Figure 8. Shankare Hill: SEM-BSE image of copper slag SMB22 showing fully crystallised fayalite olivines and magnetite spinels. 


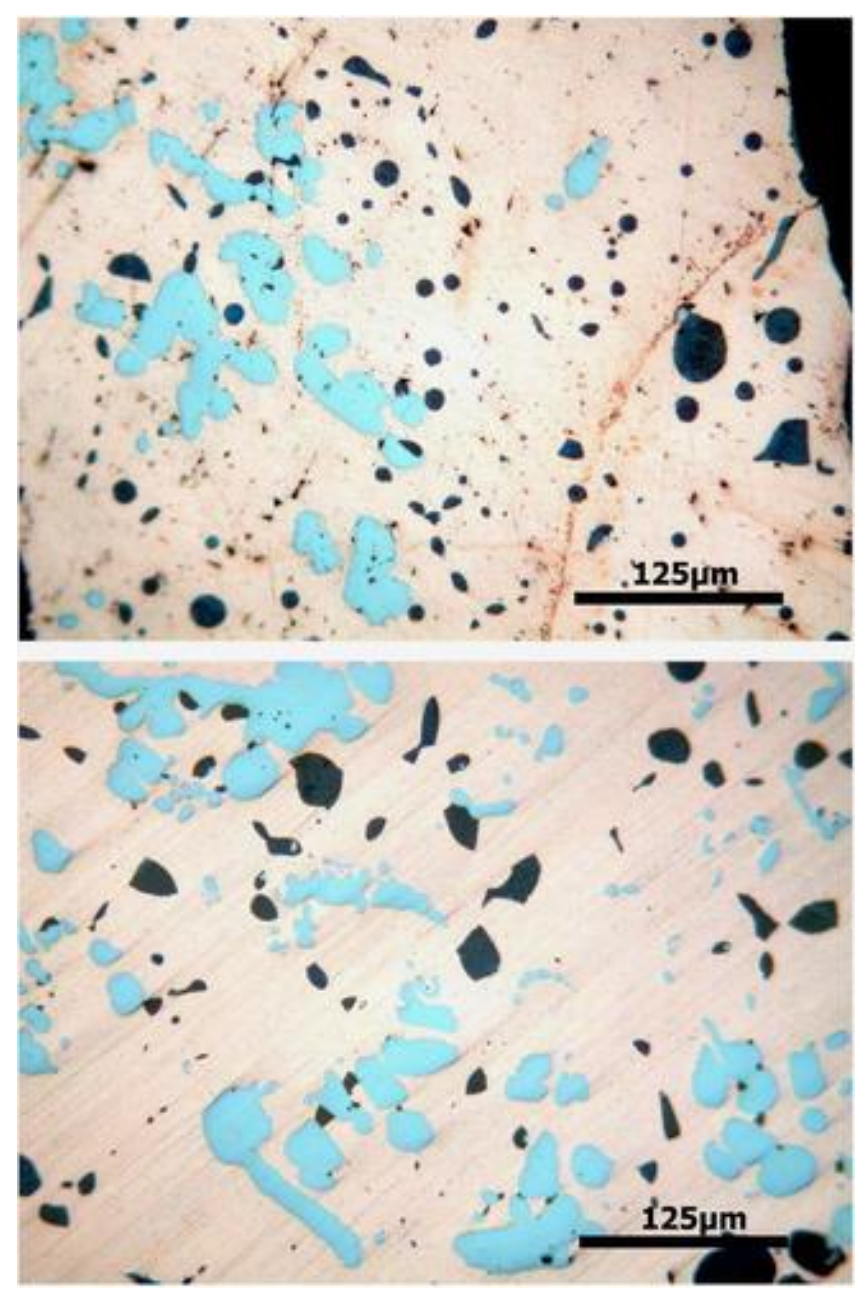

Figure 9. Shankare Hill: photomicrographs of copper prills trapped inside slag samples SHA8NWL (top) and SHAMK18(3) (bottom) showing exsolved iron light blue and copper sulphide inclusions dark green (taken under plane polarised light (200x)). 


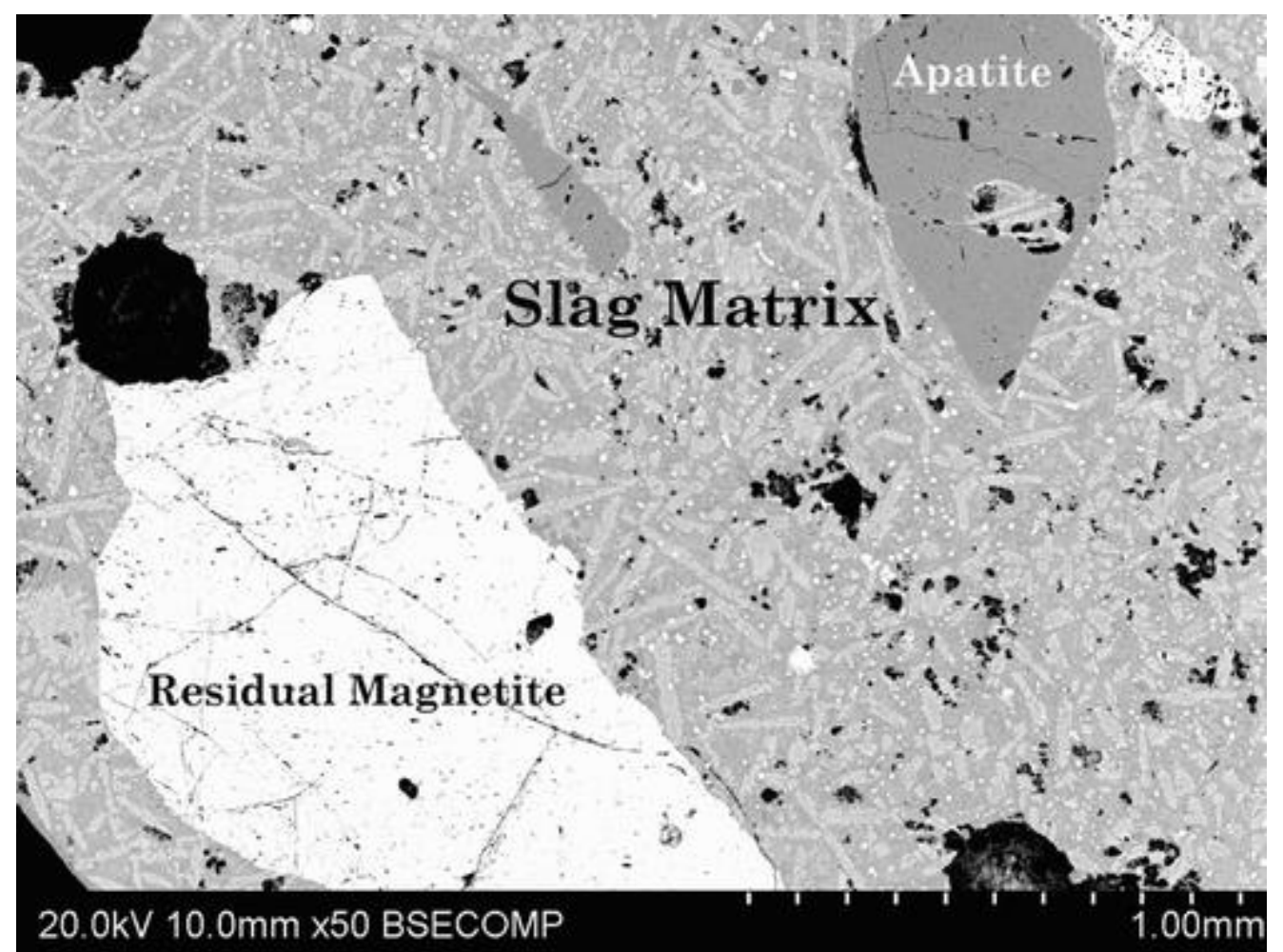

Figure 10. Shankare Hill: SEM-BSE image of sample SHA8NWL showing undissolved minerals in a copper slag matrix. 


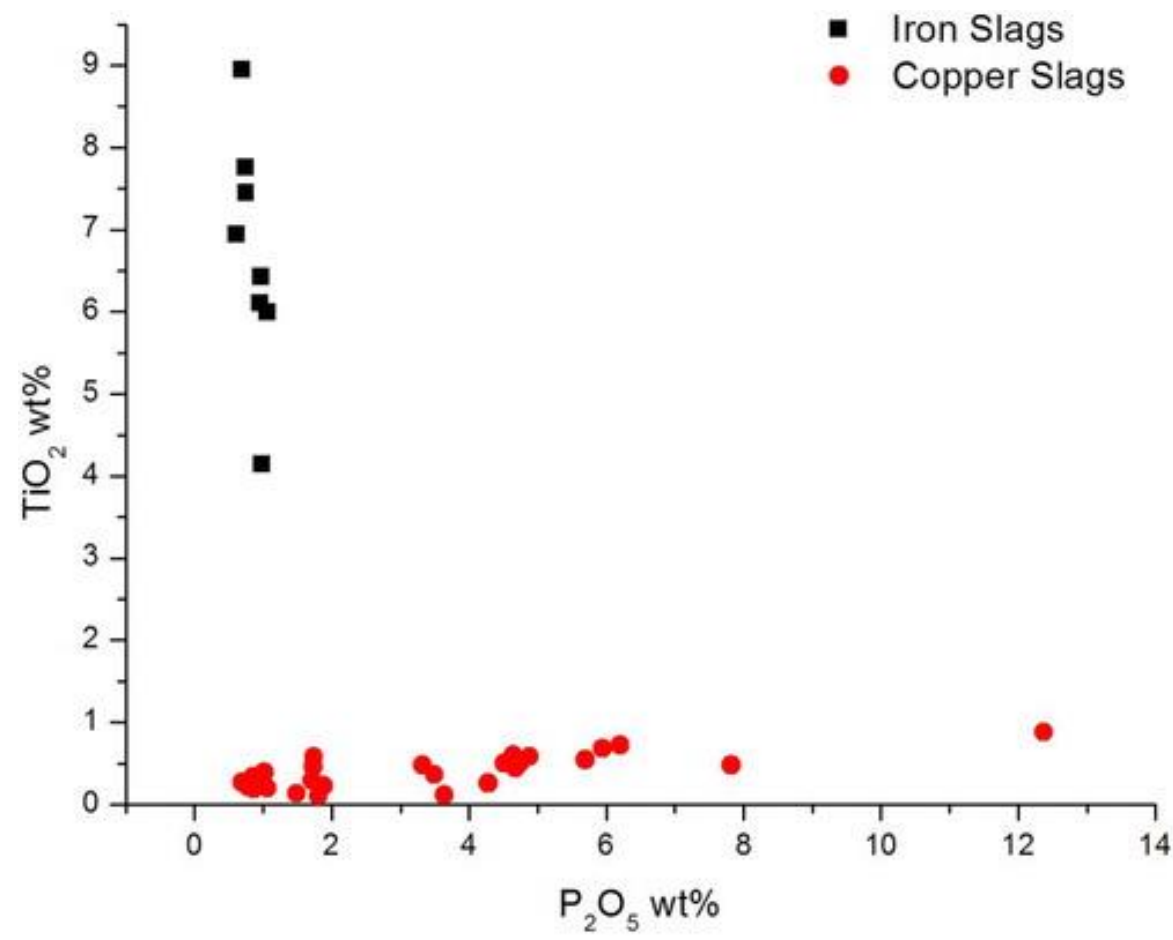

Figure 11. Shankare Hill: scatter plot of TiO2 against P2O5 showing the distinction between titanium rich iron slags from phosphorus-rich copper slags. The data are based on 'bulk' SEM-EDS area scans. 

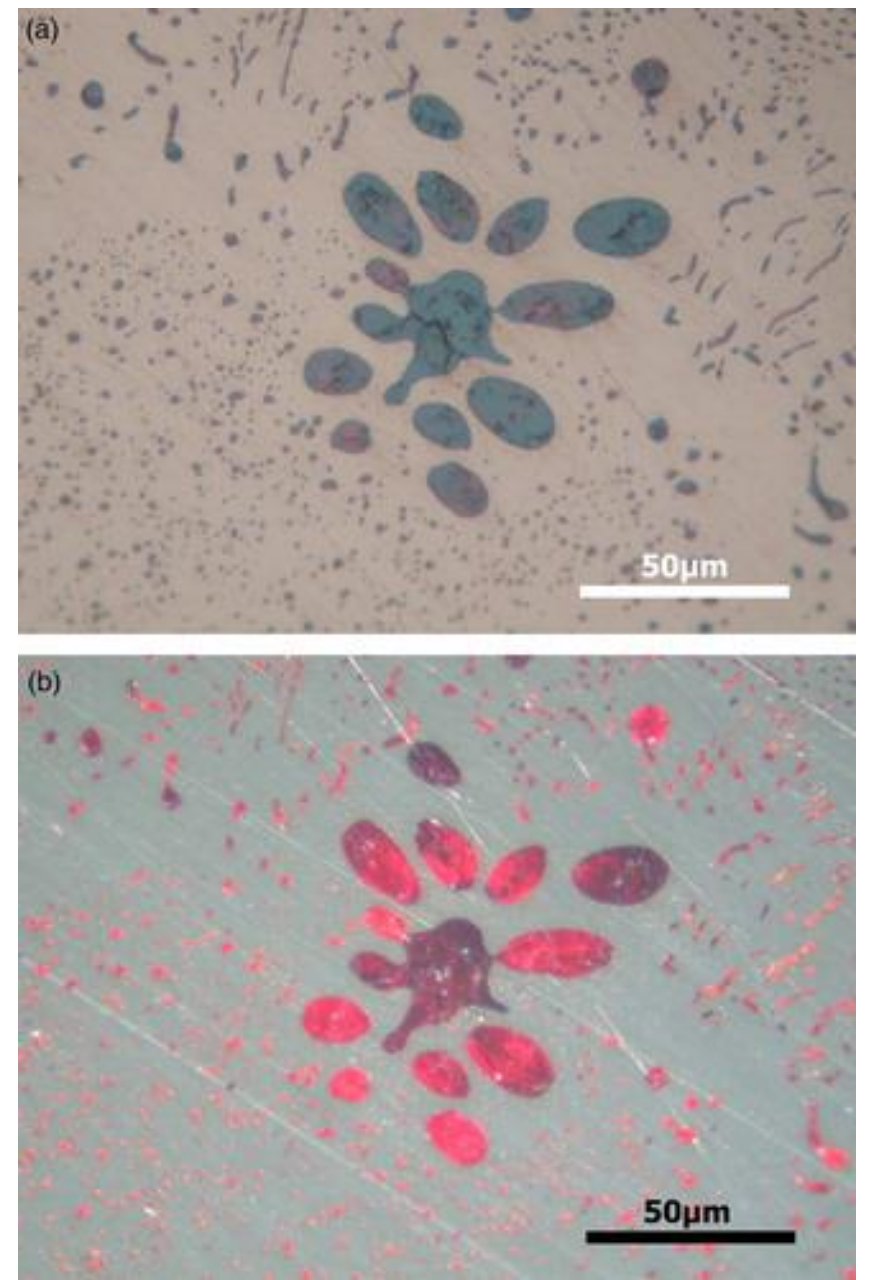

Figure 12. Shankare Hill: a) photomicrograph of metal coating adhering to crucible SMB21(3) showing the effects of oxidation during the melting process which resulted in the formation of cuprite (taken under plane-polarised light (500x)); b) photomicrograph of metal coating adhering to crucible SMB21(3) showing the effects of oxidation during the melting process that resulted in the formation of cuprite (taken under cross-polarised light (500x)). 


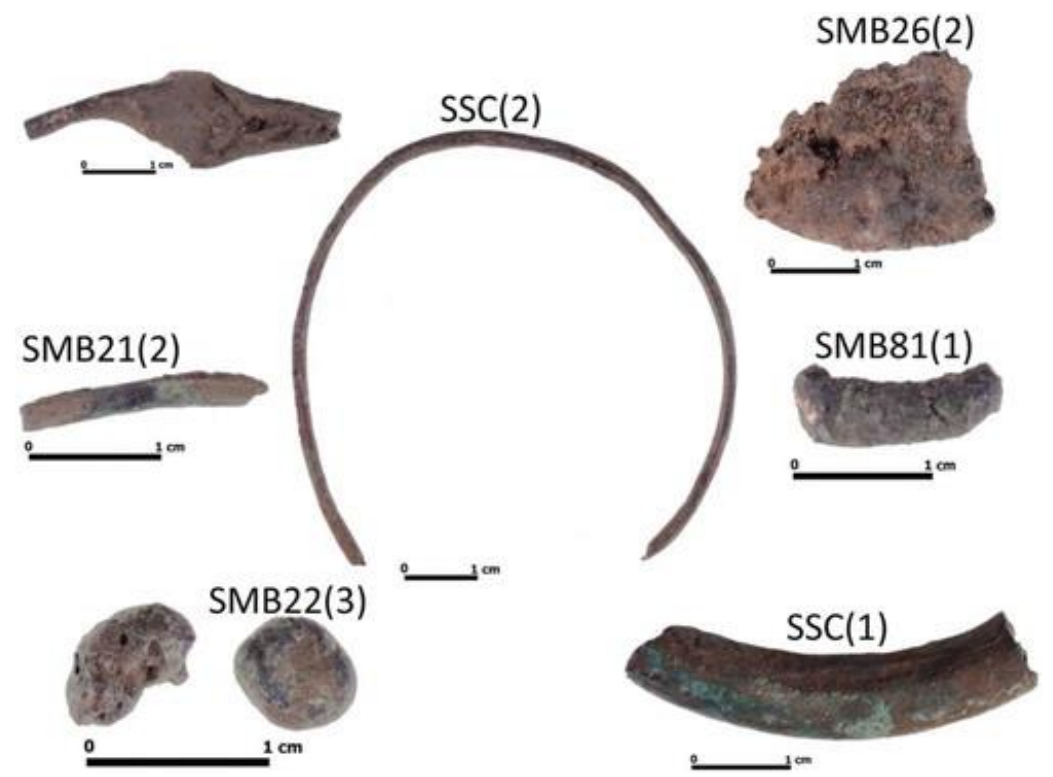

Figure 13. Part of the copper metal artefact assemblage recovered from Shankare Hill in the $\mathbf{2 0 1 0}$ field season. 


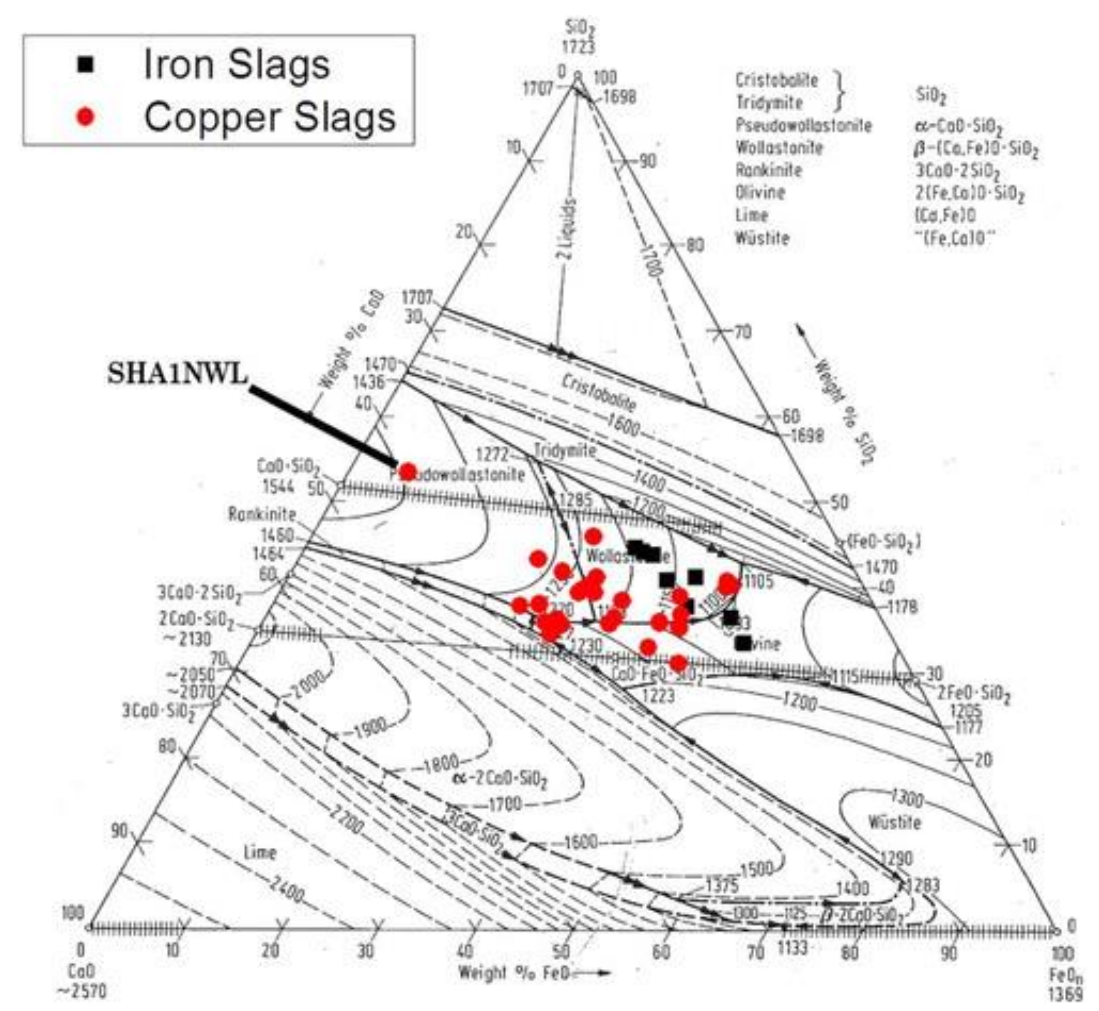

Figure 14. Plot of 'bulk' SEM-EDS results of the Shankare smelting slag samples on a FeO-SiO2(TiO2+Al2O3)-CaO(+MgO+P2O5). (Phase diagram adapted from Kowalski et al. 1995RIDCIT0059:126). 


\begin{tabular}{|c|c|c|c|c|c|c|c|c|c|c|c|c|c|c|c|c|}
\hline Sample & Context & Group & $\mathrm{Na}_{2} \mathrm{O}$ & MgO & $\mathrm{Al}_{2} \mathrm{O}_{3}$ & $\mathrm{SiO}_{2}$ & $\mathrm{P}_{2} \mathrm{O}_{5}$ & $\mathrm{SO}_{3}$ & $\mathrm{~K}_{2} \mathrm{O}$ & $\mathrm{CaO}$ & $\mathrm{TiO}_{2}$ & MnO & $\mathrm{FeO}$ & CuO & $\mathrm{BaO}$ & Sum \\
\hline SHA1T & Scatter 1 & $\mathrm{MX}$ & 0.0 & 0.3 & 0.1 & 1.3 & 6.0 & 0.1 & 0.0 & 18.3 & 0.0 & 0.1 & 16.7 & 12.7 & 0.0 & 55.7 \\
\hline SHA11NEL & Scatter 2 & ML & 0.0 & 0.1 & 0.1 & 2.3 & 0.5 & 1.1 & 0.0 & 2.4 & 0.0 & 0.0 & 34.1 & 35.9 & 0.1 & 76.7 \\
\hline SHA12NEL & Scatter 2 & ML & 0.0 & 0.2 & 0.1 & 1.5 & 0.3 & 0.2 & 0.0 & 16.4 & 0.0 & 0.1 & 20.4 & 29.7 & 0.0 & 69.0 \\
\hline SHA13NEL & Scatter 2 & ML & 0.0 & 0.2 & 0.2 & 0.7 & 0.3 & 0.1 & 0.0 & 0.1 & 0.1 & 0.0 & 8.3 & 59.6 & 0.0 & 69.5 \\
\hline SHA14NEL & Scatter 2 & ML & 0.0 & 0.1 & 0.1 & 0.8 & 0.2 & 0.1 & 0.0 & 9.8 & 0.1 & 0.0 & 11.0 & 45.6 & 0.0 & 67.9 \\
\hline SHA15NEL & Scatter 2 & ML & 0.0 & 0.4 & 0.6 & 2.1 & 0.3 & 0.0 & 0.0 & 1.0 & 0.0 & 0.1 & 0.3 & 57.9 & 0.1 & 62.7 \\
\hline SHA16NEL & Scatter 2 & ML & 0.0 & 0.3 & 0.1 & 1.3 & 0.2 & 4.5 & 0.0 & 0.2 & 0.1 & 0.1 & 4.4 & 54.7 & 0.1 & 66.0 \\
\hline SHA2NWL & Scatter 7 & ML & 0.0 & 10.5 & 0.0 & 42.8 & 0.7 & 1.2 & 0.1 & 13.5 & 0.1 & 0.1 & 4.5 & 22.2 & 1.9 & 97.7 \\
\hline SMB22(4) & SHAM1 & $\mathrm{MX}$ & 0.0 & 1.4 & 1.3 & 1.2 & 0.3 & 0.0 & 0.0 & 0.4 & 0.0 & 0.1 & 62.8 & 7.5 & 0.0 & 75.2 \\
\hline SMB22(5) & SHAM1 & ML & 0.0 & 2.4 & 0.1 & 7.1 & 0.8 & 1.6 & 0.0 & 2.8 & 0.0 & 0.1 & 25.4 & 29.9 & 0.0 & 70.1 \\
\hline SMB26(2) & SHAM1 & MX & 0.0 & 0.1 & 0.0 & 45.0 & 0.1 & 0.1 & 0.0 & 0.6 & 0.0 & 0.0 & 14.5 & 28.0 & 0.0 & 88.5 \\
\hline SMB26(3) & SHAM1 & ML & 0.0 & 0.2 & 0.1 & 3.1 & 0.0 & 0.2 & 0.0 & 0.2 & 0.0 & 0.1 & 27.9 & 27.2 & 0.0 & 59.0 \\
\hline SMB26(4) & SHAM1 & ML & 0.0 & 6.0 & 2.1 & 6.4 & 0.2 & 0.0 & 0.0 & 0.7 & 0.0 & 0.0 & 1.1 & 56.2 & 0.0 & 72.7 \\
\hline SMB27(1) & SHAM1 & ML & 0.0 & 0.3 & 0.2 & 1.2 & 0.1 & 2.5 & 0.0 & 4.4 & 0.0 & 0.0 & 6.2 & 52.7 & 0.0 & 67.6 \\
\hline
\end{tabular}

Table 1. Shankare Hill: average SEM-EDS results of at least five area scans of the presumed ore samples recovered (weight \%). The results are not normalised due to the presence of structural water and carbonates prevalent in secondary ores. 


\begin{tabular}{|c|c|c|c|c|c|c|c|c|c|c|c|c|c|c|c|}
\hline Sample & Context & $\mathrm{Na}_{2} \mathrm{O}$ & MgO & $\mathrm{Al}_{2} \mathrm{O}_{3}$ & $\mathrm{SiO}_{2}$ & $\mathrm{P}_{2} \mathrm{O}_{5}$ & $\mathrm{SO}_{3}$ & $\mathrm{~K}_{2} \mathrm{O}$ & $\mathrm{CaO}$ & $\mathrm{TiO}_{2}$ & $\mathrm{MnO}$ & $\mathrm{FeO}$ & $\mathrm{CuO}$ & $\mathrm{Al}_{2} \mathrm{O}_{3}$ & $\mathrm{SiO}_{2}$ \\
\hline SHA1NEL & SHASH1 & 0.7 & 4.4 & 4.6 & 24.3 & 0.7 & 0.1 & 2.2 & 13.6 & 7.8 & 0.4 & 41.4 & 0.0 & 1 & 5 \\
\hline SHA2NEL & SHASH1 & 0.9 & 4.2 & 5.6 & 29.2 & 0.8 & 0.1 & 2.3 & 14.2 & 7.4 & 0.3 & 34.9 & 0.1 & 1 & 5 \\
\hline SHA3NEL & SHASH1 & 0.7 & 5.1 & 4.8 & 27.8 & 1.0 & 0.1 & 3.1 & 12.9 & 6.4 & 0.4 & 37.5 & 0.1 & 1 & 6 \\
\hline SHA4NEL & SHASH1 & 0.9 & 4.8 & 6.0 & 30.4 & 1.0 & 0.1 & 2.7 & 14.2 & 6.1 & 0.3 & 33.7 & 0.0 & 1 & 5 \\
\hline SHA5NEL & SHASH1 & 0.4 & 4.6 & 4.7 & 23.9 & 0.6 & 0.2 & 1.7 & 9.8 & 6.9 & 0.3 & 46.7 & 0.2 & 1 & 5 \\
\hline SHA6NEL & SHASH1 & 0.8 & 4.3 & 5.6 & 28.0 & 1.1 & 0.1 & 2.9 & 10.7 & 6.0 & 0.3 & 40.2 & 0.0 & 1 & 5 \\
\hline SHA7NEL & SHASH1 & 0.8 & 4.7 & 5.4 & 28.7 & 0.7 & 0.1 & 2.3 & 15.1 & 8.9 & 0.4 & 32.8 & 0.0 & 1 & 5 \\
\hline SHA8NEL & SHASH1 & 0.7 & 4.0 & 4.5 & 23.6 & 1.0 & 0.1 & 2.5 & 10.0 & 4.1 & 0.3 & 49.1 & 0.1 & 1 & 5 \\
\hline
\end{tabular}

Table 2. Shankare Hill: average SEM-EDS 'bulk' chemical results of iron production slags. The results are presented in wt \% and normalised to $100 \%$. The last two columns are showing the alumina to silica ratio.

\begin{tabular}{|c|c|c|c|c|c|c|c|c|c|c|c|c|c|c|c|c|}
\hline Sample & Context & $\mathrm{Na}_{2} \mathrm{O}$ & MgO & $\mathrm{Al}_{2} \mathrm{O}_{3}$ & $\mathrm{SiO}_{2}$ & $\mathrm{P}_{2} \mathrm{O}_{5}$ & $\mathrm{SO}_{3}$ & $\mathrm{~K}_{2} \mathrm{O}$ & $\mathrm{CaO}$ & $\mathrm{TiO}_{2}$ & $\mathrm{~V}_{2} \mathrm{O}_{5}$ & $\mathrm{MnO}$ & $\mathrm{FeO}$ & $\mathrm{CuO}$ & $\mathrm{Al}_{2} \mathrm{O}_{3}$ & $\mathrm{SiO}_{2}$ \\
\hline SHA4NEL & SHASH1 & 0.49 & 3.82 & 4.78 & 30.25 & 0.81 & 0.16 & 2.39 & 13.70 & 6.32 & 0.10 & 0.35 & 36.81 & 0.02 & 1 & 6 \\
\hline SHA6NEL & SHASH1 & 0.58 & 3.51 & 4.48 & 29.04 & 0.90 & 0.17 & 2.51 & 11.21 & 5.89 & 0.10 & 0.31 & 41.28 & 0.01 & 1 & 6 \\
\hline SHA7NEL & SHASH1 & 0.59 & 3.48 & 4.21 & 27.60 & 0.50 & 0.11 & 1.81 & 12.94 & 8.41 & 0.09 & 0.34 & 39.91 & 0.01 & 1 & 7 \\
\hline SHA8NEL & SHASH1 & 0.47 & 3.08 & 3.45 & 24.25 & 0.81 & 0.19 & 2.14 & 9.29 & 3.79 & 0.10 & 0.30 & 52.11 & 0.02 & 1 & 7 \\
\hline
\end{tabular}

Table 3. Shankare Hill: average ED-XRF bulk chemical results of iron production slags. The results are presented in wt \% and not normalised. The last two columns show the alumina to silica ratio. 


\begin{tabular}{|c|c|c|c|c|c|}
\hline Sample & Context & Chalcopyrite & Fluoroapatite & Magnetite & Quartz \\
\hline SHA1NWL & Scatter 7 & & $\checkmark$ & & \\
\hline SHA6NWL & Scatter 7 & & $\checkmark$ & & \\
\hline SHA7NWL & Scatter 7 & & & $\checkmark$ & \\
\hline SHA8NWL & Scatter 7 & & $\checkmark$ & $\checkmark$ & \\
\hline SHA9NEL & Scatter 2 & & $\checkmark$ & $\checkmark$ & \\
\hline SHA9NWL & Scatter 7 & & $\checkmark$ & $\checkmark$ & $\checkmark$ \\
\hline SHA10NEL & Scatter 2 & & $\checkmark$ & $\checkmark$ & \\
\hline SHA10NWL & Scatter 7 & & $\checkmark$ & & \\
\hline SHAMK7(1) & Scatter 7 & $\checkmark$ & & & $\checkmark$ \\
\hline SHAMK8(1) & Scatter 8 & & & $\checkmark$ & \\
\hline SHAMK18(1) & Scatter 18 & & & $\checkmark$ & \\
\hline SHAMK18(2) & Scatter 18 & & & & $\checkmark$ \\
\hline SHAMK18(3) & Scatter 18 & & $\checkmark$ & $\checkmark$ & \\
\hline SHAMK27(3) & Scatter 27 & & $\checkmark$ & & $\checkmark$ \\
\hline SHARS(2) & Scatter 1 & & $\checkmark$ & & \\
\hline SMB21(1) & SHAM1 & & & $\checkmark$ & $\checkmark$ \\
\hline SMB22(1) & SHAM1 & & $\checkmark$ & & $\checkmark$ \\
\hline SMB22(2) & SHAM1 & & $\checkmark$ & $\checkmark$ & \\
\hline SMB23(1) & SHAM1 & & & & $\checkmark$ \\
\hline SMB24(1) & SHAM1 & & $\checkmark$ & $\checkmark$ & $\checkmark$ \\
\hline SMB26(1) & SHAM1 & & $\checkmark$ & & $\checkmark$ \\
\hline
\end{tabular}

Table 4. Shankare Hill: data showing the presence $(\checkmark)$ and absence of unreacted and partially reduced minerals in the copper slags. 


\begin{tabular}{|c|c|c|c|c|c|c|c|c|c|c|c|c|c|c|c|}
\hline Sample & Context & $\mathrm{Na}_{2} \mathrm{O}$ & MgO & $\mathrm{Al}_{2} \mathrm{O}_{3}$ & $\mathrm{SiO}_{2}$ & $\mathbf{P}_{2} \mathbf{O}_{5}$ & $\mathrm{SO}_{3}$ & $\mathrm{~K}_{2} \mathrm{O}$ & $\mathrm{CaO}$ & $\mathrm{TiO}_{2}$ & $\mathrm{MnO}$ & $\mathrm{FeO}$ & $\mathrm{CuO}$ & $\mathrm{Al}_{2} \mathrm{O}_{3}$ & $\mathrm{SiO}_{2}$ \\
\hline SHA1NWL & Scatter 7 & 0.5 & 10.2 & 0.8 & 51.4 & 4.7 & 0.1 & 0.7 & 24.9 & 0.4 & 0.1 & 5.8 & 0.3 & 1 & 65 \\
\hline SHA4NWL & Scatter 7 & 0.4 & 4.2 & 3.2 & 35.2 & 5.7 & 0.1 & 1.1 & 18.8 & 0.5 & 0.1 & 30.3 & 0.3 & 1 & 11 \\
\hline SHA5NWL & Scatter 7 & 0.5 & 4.1 & 3.1 & 34.7 & 5.9 & 0.0 & 1.2 & 17.4 & 0.7 & 0.2 & 31.5 & 0.6 & 1 & 11 \\
\hline SHA6NWL & Scatter 7 & 0.5 & 3.7 & 3.7 & 35.1 & 4.9 & 0.1 & 1.3 & 18.9 & 0.6 & 0.2 & 30.8 & 0.3 & 1 & 9 \\
\hline SHA7NWL & Scatter 7 & 0.3 & 5.6 & 2.4 & 33.0 & 4.5 & 0.0 & 0.8 & 17.0 & 0.5 & 0.2 & 35.4 & 0.3 & 1 & 14 \\
\hline SHA8NWL & Scatter 7 & 0.5 & 3.5 & 3.1 & 34.7 & 6.2 & 0.1 & 1.0 & 19.3 & 0.7 & 0.2 & 29.9 & 0.7 & 1 & 11 \\
\hline SHA9NEL & Scatter 2 & 0.5 & 6.0 & 2.3 & 34.3 & 3.3 & 0.1 & 0.8 & 26.6 & 0.5 & 0.2 & 24.9 & 0.5 & 1 & 15 \\
\hline SHA9NWL & Scatter 7 & 0.5 & 3.4 & 3.1 & 34.6 & 0.9 & 0.1 & 0.9 & 14.7 & 0.3 & 0.1 & 40.4 & 1.0 & 1 & 11 \\
\hline SHA10NEL & Scatter 2 & 0.7 & 2.9 & 3.1 & 30.4 & 12.4 & 0.1 & 1.0 & 16.8 & 0.9 & 0.3 & 29.5 & 2.1 & 1 & 10 \\
\hline SHA10NWL & Scatter 7 & 0.4 & 3.7 & 3.4 & 36.1 & 4.6 & 0.0 & 1.3 & 18.0 & 0.6 & 0.1 & 30.8 & 0.8 & 1 & 11 \\
\hline SHAMK7(1) & Scatter 7 & 0.5 & 3.8 & 3.1 & 30.0 & 1.9 & 1.5 & 1.4 & 28.1 & 0.2 & 0.2 & 29.0 & 0.4 & 1 & 10 \\
\hline SHAMK7(2) & Scatter 7 & 0.4 & 6.6 & 2.8 & 32.3 & 1.8 & 0.2 & 0.9 & 25.9 & 0.1 & 0.3 & 28.3 & 0.5 & 1 & 12 \\
\hline SHAMK7(3) & Scatter 7 & 0.2 & 5.7 & 1.2 & 30.7 & 1.5 & 0.1 & 0.4 & 17.8 & 0.1 & 0.3 & 40.0 & 1.8 & 1 & 25 \\
\hline SHAMK8(1) & Scatter 8 & 0.2 & 5.8 & 2.1 & 32.6 & 4.7 & 0.1 & 0.5 & 22.1 & 0.5 & 0.2 & 29.2 & 2.0 & 1 & 16 \\
\hline SHAMK9(1) & Scatter 9 & 0.7 & 3.4 & 3.2 & 32.1 & 1.7 & 0.1 & 1.0 & 14.8 & 0.6 & 0.1 & 41.5 & 1.0 & 1 & 10 \\
\hline SHAMK18(1) & Scatter 18 & 0.1 & 5.3 & 1.1 & 42.7 & 1.7 & 0.0 & 0.3 & 17.2 & 0.5 & 0.3 & 27.9 & 2.9 & 1 & 38 \\
\hline SHAMK18(2) & Scatter 18 & 0.2 & 6.9 & 1.6 & 40.6 & 1.7 & 0.1 & 0.5 & 22.7 & 0.3 & 0.3 & 24.0 & 1.2 & 1 & 26 \\
\hline SHAMK18(3) & Scatter 18 & 0.5 & 3.4 & 3.2 & 31.7 & 3.6 & 0.2 & 0.8 & 15.6 & 0.1 & 0.2 & 39.8 & 0.9 & 1 & 10 \\
\hline SHAMK18(4) & Scatter 18 & 0.3 & 1.4 & 1.8 & 37.3 & 4.3 & 0.0 & 0.7 & 8.2 & 0.3 & 0.2 & 45.0 & 0.5 & 1 & 21 \\
\hline SHAMK27(3) & Scatter 27 & 0.4 & 3.4 & 2.4 & 36.6 & 0.9 & 0.0 & 0.7 & 9.0 & 0.3 & 0.2 & 43.9 & 2.2 & 1 & 15 \\
\hline SHARS(2) & Scatter 1 & 0.2 & 4.7 & 2.1 & 34.7 & 7.8 & 0.1 & 0.5 & 21.3 & 0.5 & 0.2 & 26.7 & 1.3 & 1 & 16 \\
\hline SMB21(1) & SHAM1 & 0.3 & 5.6 & 1.6 & 32.1 & 1.1 & 0.2 & 0.7 & 13.8 & 0.2 & 0.3 & 41.4 & 2.7 & 1 & 20 \\
\hline SMB22(1) & SHAM1 & 0.3 & 2.7 & 2.5 & 36.3 & 0.8 & 0.2 & 0.9 & 9.6 & 0.2 & 0.1 & 44.8 & 1.6 & 1 & 15 \\
\hline SMB22(2) & SHAM1 & 0.3 & 5.1 & 2.6 & 31.8 & 1.0 & 0.6 & 0.6 & 21.4 & 0.4 & 0.2 & 34.6 & 1.4 & 1 & 12 \\
\hline SMB23(1) & SHAM1 & 0.5 & 4.5 & 2.6 & 34.5 & 0.7 & 0.3 & 0.9 & 19.8 & 0.3 & 0.2 & 34.7 & 1.1 & 1 & 13 \\
\hline SMB24(1) & SHAM1 & 0.2 & 3.6 & 1.2 & 28.9 & 0.9 & 0.1 & 0.3 & 18.4 & 0.2 & 0.2 & 43.9 & 2.1 & 1 & 25 \\
\hline SMB26(1) & SHAM1 & 0.3 & 3.0 & 2.2 & 38.4 & 3.5 & 0.0 & 0.6 & 23.1 & 0.4 & 0.2 & 27.2 & 1.0 & 1 & 17 \\
\hline
\end{tabular}

Table 5. Shankare Hill: average SEM-EDS 'bulk' chemical results of copper slags together with alumina to silica ratios. The data are normalised and given in wt \%. 


\begin{tabular}{|c|c|c|c|c|c|c|c|c|c|c|c|c|c|c|}
\hline Sample & Context & Target & $\mathrm{Na}_{2} \mathrm{O}$ & MgO & $\mathrm{Al}_{2} \mathrm{O}_{3}$ & $\mathrm{SiO}_{2}$ & $\mathrm{P}_{2} \mathrm{O}_{5}$ & $\mathrm{SO}_{3}$ & $\mathrm{~K}_{2} \mathrm{O}$ & $\mathrm{CaO}$ & $\mathrm{TiO}_{2}$ & $\mathrm{MnO}$ & $\mathrm{FeO}$ & $\mathrm{CuO}$ \\
\hline SHA3NWL & Scatter 7 & Ceramic matrix & 1.8 & 3.1 & 13.3 & 62.0 & 0.4 & 0.6 & 2.6 & 3.2 & 2.0 & 0.1 & 10.8 & 0.1 \\
\hline SMB21(3) & SHAM1 & Ceramic matrix & 2.3 & 1.8 & 20.6 & 54.4 & 0.4 & 0.1 & 2.2 & 3.3 & 1.6 & 0.1 & 13.1 & 0.1 \\
\hline $\operatorname{SMB23(2)}$ & SHAM1 & Ceramic matrix & 2.0 & 1.0 & 15.8 & 67.3 & 0.2 & 0.0 & 3.4 & 2.9 & 1.0 & 0.1 & 6.2 & 0.1 \\
\hline SMB27(1) & SHAM1 & Ceramic matrix & 2.9 & 1.5 & 17.2 & 59.4 & 0.5 & 0.1 & 3.6 & 5.3 & 0.9 & 0.1 & 8.4 & 0.1 \\
\hline SSHB23(1) & SHASH1 & Ceramic matrix & 2.4 & 2.3 & 19.4 & 61.1 & 0.3 & 0.1 & 1.8 & 3.2 & 1.0 & 0.0 & 8.4 & 0.0 \\
\hline SSHB23(2) & SHASH1 & Ceramic matrix & 2.5 & 2.4 & 21.6 & 58.7 & 0.3 & 0.1 & 2.4 & 2.5 & 0.9 & 0.1 & 8.6 & 0.1 \\
\hline
\end{tabular}

Table 6. Shankare Hill: average SEM-EDS results of five area scans of the ceramic fabrics of the crucibles. The results are given in wt $\%$ and normalised to $100 \%$.

\begin{tabular}{|c|c|c|c|c|c|c|c|c|c|c|c|c|c|c|}
\hline Sample & Context & Target & $\mathrm{Na}_{2} \mathrm{O}$ & MgO & $\mathrm{Al}_{2} \mathrm{O}_{3}$ & $\mathrm{SiO}_{2}$ & $\mathrm{P}_{2} \mathrm{O}_{5}$ & $\mathrm{SO}_{3}$ & $\mathrm{~K}_{2} \mathrm{O}$ & $\mathrm{CaO}$ & $\mathrm{TiO}_{2}$ & MnO & $\mathrm{FeO}$ & $\mathrm{CuO}$ \\
\hline SHA3NWL & Scatter 7 & Vitrified layer & 1.3 & 3.9 & 10.4 & 46.6 & 1.6 & 0.0 & 2.3 & 23.2 & 2.1 & 0.2 & 8.1 & 0.2 \\
\hline SMB21(3) & SHAM1 & Slag lining & 1.5 & 3.3 & 7.6 & 43.3 & 0.9 & 0.1 & 4.3 & 15.9 & 0.7 & 0.1 & 9.8 & 12.6 \\
\hline $\operatorname{SMB23(2)}$ & SHAM1 & Vitrified layer & 0.9 & 3.7 & 10.0 & 35.7 & 15.9 & 0.0 & 1.4 & 26.1 & 0.8 & 0.1 & 5.3 & 0.2 \\
\hline SMB27(1) & SHAM1 & Slag lining & 1.7 & 2.7 & 9.2 & 42.8 & 5.5 & 0.1 & 2.7 & 18.3 & 1.5 & 0.1 & 9.9 & 5.6 \\
\hline SSHB23(1) & SHASH1 & Slag lining & 1.7 & 3.1 & 10.5 & 43.6 & 0.8 & 0.0 & 2.7 & 25.2 & 0.6 & 0.1 & 9.9 & 1.7 \\
\hline SSHB23(2) & SHASH1 & Slag lining & 1.7 & 2.9 & 10.9 & 43.3 & 0.6 & 0.1 & 2.6 & 24.4 & 0.6 & 0.1 & 10.6 & 2.3 \\
\hline
\end{tabular}

Table 7. Shankare Hill: average SEM-EDS results of five area scans of metallurgical debris attached to the crucibles. The results are given in wt \% and normalised to $100 \%$. 